UNITED STATES DEPARTMENT OF COMMERCE JESSE H. JONES, Secretary

NATIONAL BUREAU OF STANDARDS

LYMAN J. BRIGGS, Director

\title{
OLD GROWTH DOUGLAS FIR STANDARD STOCK DOORS
}

(SECOND EDITION)

\section{COMMERCIAL STANDARD CS73-43}

(Supersedes CS73-38)

Effective Date for New Production from June 15, 1943

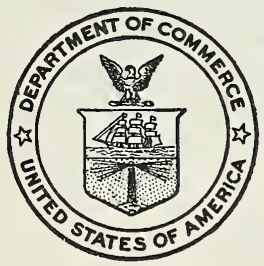

A RECORDED VOLUNTARY STANDARD OF THE TRADE

UNITED STATES

GOVERNMENT PRINTING OFFICE

WASHINGTON : 1943 


\title{
PROMULGATION
}

\author{
of \\ COMMERCIAL STANDARD CS73-43 \\ for
}

\section{OLD GROWTH DOUGLAS FIR STANDARD STOCK DOORS}

(Second Edition)

On April 4, 1938, at the instance of the Fir Door Institute, a general conference of representative manufacturers, distributors, and users of old growth Douglas fir standard stock doors adopted a recommended commercial standard for this commodity which was subsequently accepted by the trade and published as Commercial Standard CS73-38.

A recommended revision submitted by the Fir Door Institute and endorsed by the standing committee was circulated on February 27, 1943 , to the trade for written acceptance. The trade has since accepted and approved for promulgation by the United States Department of Commerce, through the National Bureau of Standards, the revised standard as shown herein.

The standard is effective for new production from June 15, 1943.

Promulgation recommended.

I. J. Fairchild,

Promulgated.

Chief, Division of Trade Standards.

Lyman J. Briggs,

Promulgation approved. Director, National Bureau of Standards.

Jesse H. Jones, Secretary of Commerce. 


\title{
OLD GROWTH DOUGLAS FIR STANDARD STOCK DOORS ${ }^{1}$
}

\author{
(Second Edition)
}

\section{COMMERCIAL STANDARD CS73-43}

\section{PURPOSE}

1. This standard is a basis for common understanding between manufacturers, distributors, and users of stock fir doors. By its general acceptance, use, and certification by labels it is hoped to increase interest in the manufacture, sale, and use of fir doors manufactured to standard grades, to the mutual advantage of all concerned.

2. In the development of these standards there is no desire to suppress architectural expression and custom made doors will still be available from the usual sources. However, the establishment of construction standards, together with universally accepted sizes and layouts, should prove highly advantageous by eliminating the causes of many misunderstandings occurring through the lack of standards, and produce economies in manufacture and sale which should be shared by the ultimate home owner.

\section{SCOPE}

3. This standard provides minimum specifications for 4 grades of stock fir doors in four thicknesses, $3 / 4,1 \frac{1}{8}, 13 / 8$, and $1 \frac{3 / 4}{4}$ inches. It covers construction, defects, and the grading tolerances for these requirements. There are standard stock layouts and designs covered in door sizes ranging as follows, and in accordance with detailed schedules of Douglas fir stock door list beginning on page 6 .

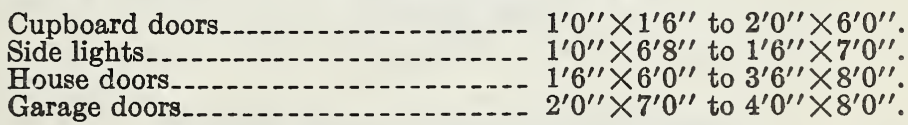

\section{GENERAL REQUIREMENTS}

4. All commercial standard fir doors shall meet the following general requirements:

5. Material.-Doors shall be made of kiln-dried, old growth Douglas fir.

6. Workmanship.-Doors shall be well manufactured and machined, and both faces shall have flat surfaces; that is, with stiles, rails, and panels smoothly sanded.

1 Jld growth Douglas fir is a term generally applied to distinguish the wood developed in the later strges of the tree's growth. It is generally free from knots; of medium density with fairly close, uniformly spaced growth rings; and usually of uniform light yellowish or pinkish color. Contrasted to this is the early growth sometimes referred to as red fir, which, while of the same species and perhaps of the same tree, is generally knotty, of low density, with wide and sometimes irregular growth rings, and usually a red color. 
7. Construction.-Doors shall be assembled by what is known as "dowelled construction"; that is, stiles and rails to be bored to receive fir dowels not less than $\%$ inch in diameter by 5 inches long for doors $\% / 4$ inch thick, and not less than $\% / 8$ inch in diameter by 5 inches long for doors $1 \frac{1}{8}, 13 / 8$, and $1 \frac{13}{4}$ inches thick. The dowels shall have glue grooves. Dowels shall be set in glue and extend approximately onehalf their length in to each stile and rail, and assembled under pressure. Because of the fact that all present standard door boring machines are built for 23/4inch dowel centers, the required number of dowels used in joining rails to stiles are therefore limited according to the width of the rails, and shall be based on a minimum number of dowels at each ond of rails as follows:

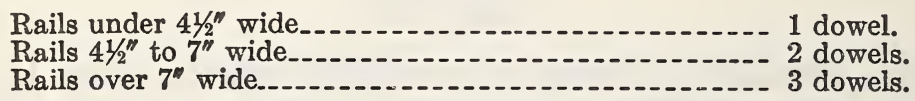

8. Sticking.-Three-eighths inch "bead and cove" or "ovolo" sticking shall be standard on all standard doors. "Bead and cove" sticking will be furnished, unless otherwise specified. (See fig. 1.)

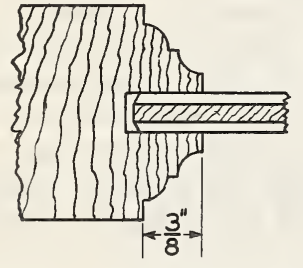

BEAD \& COVE STICKING

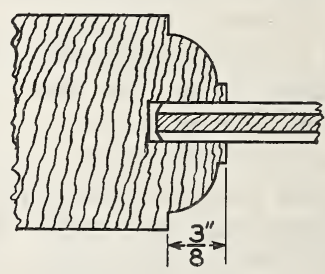

OVOLO STICKING

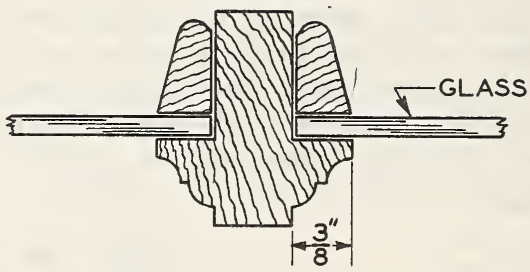

STANDARD PATTERN GLASS BEAD

FIgURE 1.-Sticking.

Defective sticking which may develop in machining must be carefully repaired or neatly replaced.

9. Thicknesses.-Doors shall be in the following thicknesses, and a thickness tolerance of minus $1 / 16$ inch shall be allowed:

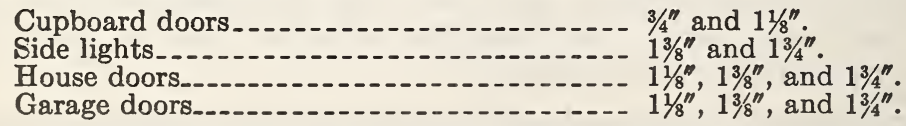

10. In standard practice, a length and width tolerance of plus $1 / 8$ inch shall be allowed. When so ordered, house doors will be trimmed to standard lengths with a toleranci of plus or minus $1 / 32$ inch. When 
so trimmed, protection strips or skid blocks shall be applied to top and bottom ends.

\section{INSPECTION AND LABELING}

11. All doors guaranteed to conform to the Commercial Standard grading rules shall be grade-marked by stamp, brand, or label. All complaints involving the quality of any shipment must be made within 5 days from receipt thereof.

\section{DETAIL REQUIREMENTS}

12. Standard stock layouts and designs to which the subsequent design numbers refer are to be found in the Douglas fir stock door list beginning on page 6.

13. It is impossible to maintain absolutely arbitrary rules fixing grades, and slight variations within reason and governed by practical common sense may be expected. A shipment of any grado must represent a fair average of that grade.

14. Doors shall be graded on both sides or faces in accordance with the following standard grades. Grades $A, B$, and $C$, covering standard house doors, will be furnished in $1 \frac{3}{8}$ - and $13 / 4$-inch thicknesses only. Standard side lights, and doors of special layout or design will be furnished in grade $A$ only. Cupboard doors will be furnished in $B$ and better grade only. House doors $1 \frac{1}{8}$ inch thick will be furnished in "millrun" grade only.

\section{HOUSE DOORS}

\section{Grade A.-Recommended for Paint or Natural or Stain Finish}

15. Stiles and rails.-This stock shall be of 100-percent heartwood, all vertical grain old growth Douglas fir, the faces of which must be clear, with the exception that each stile may contain one carefully repaired pitch seam on each side, provided that such pitch seam does not extend through the piece nor exceed $3 \frac{1}{2}$ inches in length. Such pitch pockets shall be not over 35 inches from the bottom of the door. Bottom rail may contain one neatly repaired pitch seam the same as the stiles. Glued-up bottom rails are permissible in widths over $93 / 8$ inches.

16. Panels-flat veneered.-The standard thickness of 3-ply flat veneered panels shall be $1 / 4$ inch after sanding. Each face shall be of a yellowish or pinkish color or a blend of the two, and shall be from smoothly cut veneer, free from knots, splits, pitch pockets, and other open defects. Small streaks and spots of other colors are permissible, provided that they in no manner make the panel unusable for the purpose intended. Shims that occur only at the end of panels and inconspicuous well-matched patches shall be admitted.

17. Panels - solid raised. - The standard thickness of solid raised panels shall be not more than $\% 16$ inch before sanding and not less than $7 / 16$ inch after sanding. They shall be either all vertical or all slash grain in any one door, and shall conform to the grade of the stiles and rails. 


\section{Grade B.-Recommended Primarily for Paint Finish}

18. Stiles and rails.-This stock shall be of vertical grain faces, with some coarse grain permitted. It shall be sound in all respects, and may contain sap, slight stains, and burls. Stiles, bottom rails, and wide lock rails may each contain two neatly repaired pitch seams not over 9 inches in length on each side. Remaining rails and mullions may each contain not over one such defect on each side. Glued-up bottom rails are permissible.

19. Panels - flat veneered. - The standard thickness of 3-ply flat veneered panels shall be $1 / 4$ inch after sanding. Each face shall be of one or more pieces of firm smoothly cut veneer. When of more than one piece, it shall be well joined and reasonably matched for grain and color at the joints. It shall be free from knots, splits, checks, pitch pockets, and other open defects. Streaks, discolorations, sapwood, shims, and neatly made patches shall be admitted.

20. Panels-raised.-The standard thickness of raised panels shall be not more than $\% 16$ inch before sanding and not less than $7 / 16$ inch after sanding. They may be either slash or mixed grain, and shall conform to the grade of the stiles and rails. Two-piece, glued-up, solid panels are permissible.

\section{Grade C.-Recommended for Paint Finish OnLy}

21. This grade shall be manufactured and sold only in the standard designs, as specifically indicated in the layout details on pages 12 , $19,20,21$, and 22 .

22. Stiles and rails.-This stock may be of mixed grain, and may contain any amount of discolored sap or heartwood, burls, solid pitch, streaks, any number and size of repaired pitch seams, or other sound defects not otherwise permitted in the higher grades, providing it presents a solid surface. Glued-up stiles and rails are permissible.

23. Panels - flat veneered.-The standard thickness of 3-ply flat veneered panels shall be $1 / 4$ inch after sanding. Each face shall present a smooth surface suitable for painting. Discoloration, unmatched patches, shims, and pieced faces are admissible.

24. Panels---raised. - The standard thickness of raised panels shall be not more than $9 / 16$ inch before sanding and not less than $7 / 16$ inch after sanding. They shall conform to the grade of the stiles and rails. Two-piece, glued-up, solid panels are permissible.

\section{Millrun Grade}

25. Stiles and rails.-This grade shall be manufactured and sold in $1 \frac{1}{8}$-inch thickness only developed and accumulated by planing down stock too thin for $1 \frac{3}{8}$-inch thickness, consequently it will include an undetermined amount of all or any of the other grades. This grade and thickness shall be confined to the following standard designs: Storm doors, cupboard doors, F5, F117, F118, F119, and F214. (See stock door list beginning on page 6 .)

26. Panels-flat veneered. - The standard thickness of 3-ply, flat veneered panels shall be $1 / 4$ inch after sanding. They shall conform to the grades applying to grade $B$ and/or grade $C$ doors described above.

27. Panels-raised. - The standard thickness of raised panels shall be not more than $9 / 16$ inch before sanding, and not less than $7 / 16$ inch after sanding. They shall conform to the grades applying to grade $B$ and/or grade $C$ doors, described above. 


\section{GARAGE DOORS}

Manufactured primarily for paint finish in one quality only, which is described below.

28. Stiles and rails.-This stock shall be substantially all vertical grain, with accumulations of coarse or mixed grain permitted. It shall bo sound in all respects, and may contain sap, stain, burls, pitch streaks, and neatly repaired pitch seams.

29. Panels-flat veneered. -The standard thickness of 3-ply flat veneered panels shall be $1 / 4$ inch after sanding. They shall be of door panel grade $B$, as described under paragraph 19 .

30. Panels-solid raised. - The standard thickness of solid raised panels shall be not more than $\%$-inch before sanding and not less than $7 / 16$-inch after sanding. They may be vertical, slash, or mixed grain, at the option of the manufacturer, and shall conform to the grade of the stiles and rails.

31. Batten garage doors (designs F190 and F290).-The stiles and battens shall have all vertical grain faces, which shall be clear, except that neatly repaired pitch seams, not to exceed 4 inches in length, and at a minimum distance of 2 feet apart either way, will be admitted on each face of the door.

\section{DESIGNS AND LAYOUTS}

32. House doors of any design narrower than 1 foot 6 inches will befurnished with stiles $3 \%$ inchesin wid th, over-all, unless otherwise specified.

33. Measurements for stiles, rails, and muntins shown in layouts are over-all, including sticking. Glass measurements shown may vary slightly.

TABLE 1.-Door sizes (in feet and inches)

\begin{tabular}{|c|c|c|c|c|c|c|c|}
\hline \multicolumn{2}{|c|}{$\begin{array}{l}\text { Standard sizes, cupboard } \\
\text { doors }\end{array}$} & \multicolumn{2}{|c|}{ Standard sizes, house doors } & \begin{tabular}{l|} 
Standard \\
sizes, side \\
ligbts
\end{tabular} & \multicolumn{3}{|c|}{ Standard sizes, garage doors } \\
\hline $\begin{array}{l}1-0 \times 1-6 \\
1-2 \\
1-4 \\
1-6 \\
1-8 \\
1-10 \\
2-0\end{array}$ & $\begin{array}{l}1-0 \times 4-0 \\
1-2 \\
1-4 \\
1-6 \\
1-8 \\
1-10 \\
2-0\end{array}$ & $\begin{array}{l}2-0 \times 6-0 \\
2-4 \\
2-6 \\
2-8 \\
3-0 \\
2-6 \times 6-4\end{array}$ & $\begin{array}{l}1-6 \times 7-0 \\
1-8 \\
1-10 \\
2-6 \\
2-2 \\
2-4 \\
2-6 \\
0\end{array}$ & $\begin{array}{c}10^{\prime \prime} \times 6-8 \\
1-0 \\
1-2 \\
1-4 \\
1-6 \\
10^{\prime \prime} \times 6-10\end{array}$ & $\begin{array}{l}2-0 \times 7-0 \\
2-4 \\
2-6 \\
2-8 \\
3-0 \\
3-6 \\
3-9 \\
3-9\end{array}$ & $\begin{array}{l}2-0 \times 7-6 \\
2-4 \\
2-6 \\
2-8 \\
3-0 \\
3-6 \\
3-9 \\
3-9\end{array}$ & $\begin{array}{l}2-0 \times 8-6 \\
2-4 \\
2-6 \\
2-8 \\
3-0 \\
3-6 \\
3-9\end{array}$ \\
\hline $\begin{array}{l}1-0 \times 2-0 \\
1-2 \\
1-4 \\
1-6 \\
1-8 \\
1-10 \\
2-0\end{array}$ & $\begin{array}{l}1-0 \times 4-6 \\
1-2 \\
1-4 \\
1-6 \\
1-8 \\
1-10 \\
2-0\end{array}$ & $\begin{array}{l}1-6 \times 6-6 \\
1-8 \\
1-10 \\
2-0 \\
2-2 \\
2-4 \\
2-6\end{array}$ & $\begin{array}{l}2-10 \\
3-0 \\
3-4 \\
3-6 \\
2-0 \times 7-6 \\
2-4\end{array}$ & $\begin{array}{l}1-0 \\
1-2 \\
1-4 \\
1-6 \\
10^{\prime \prime} \times 7-0 \\
1-0 \\
1-2\end{array}$ & & & \\
\hline $\begin{array}{l}1-0 \times 2-6 \\
1-2 \\
1-4 \\
1-6 \\
1-8 \\
1-10 \\
2-0\end{array}$ & $\begin{array}{l}1-0 \times 5-0 \\
1-2 \\
1-4 \\
1-6 \\
1-8 \\
1-10 \\
2-0\end{array}$ & $\begin{array}{l}3-0 \\
1-6 \times 6-8 \\
1-8 \\
1-10 \\
2-0 \\
2-2\end{array}$ & $\begin{array}{l}2-8 \\
2-10 \\
3-0 \\
3-4 \\
3-6 \\
2-0 \times 8-0\end{array}$ & $1-7$ & & & \\
\hline $\begin{array}{l}1-0 \times 3-0 \\
1-2 \\
1-4 \\
1-6 \\
1-8 \\
1-10 \\
2-0\end{array}$ & $\begin{array}{l}1-0 \times 5-6 \\
1-2 \\
1-4 \\
1-6 \\
1-8 \\
1-10 \\
2-0\end{array}$ & $\begin{array}{l}2-4 \\
2-6 \\
2-8 \\
2-10 \\
3-0 \\
\\
2-0 \times 6-10 \\
2-2\end{array}$ & $\begin{array}{l}2-4 \\
2-6 \\
2-8 \\
2-10 \\
3-0 \\
3-4 \\
3-6\end{array}$ & & & & \\
\hline $\begin{array}{l}1-0 \times 3-6 \\
1-2 \\
1-4 \\
1-6 \\
1-8 \\
1-10 \\
2-0\end{array}$ & $\begin{array}{l}1-0 \times 6-0 \\
1-2 \\
1-4 \\
1-6 \\
1-8 \\
1-10 \\
2-0\end{array}$ & $\begin{array}{l}2-6 \\
2-8 \\
2-10 \\
3-0\end{array}$ & & & & & \\
\hline
\end{tabular}




\section{DOUGLAS FIR STOCK DOOR LIST}

34. The stock layouts and designs for old growth Douglas fir doors are illustrated below.

35. An index immediately follows showing the various use classifications including "front entrance doors," "interior doors," etc., and indicating the identifying stock number, a brief description of the panel arrangement, and the pages on which the illustrations and dimensions appear.

36. A second index is arranged on the basis of numerical arrangement of the stock numbers.

\section{“USE" CLASSIFICATION INDEX}

Front Entrance Doors

\begin{tabular}{|c|c|c|}
\hline Stock number & Description & Page \\
\hline $\begin{array}{l}\text { F66, F67 } \\
\text { F14485145 } \\
\text { F182 }\end{array}$ & 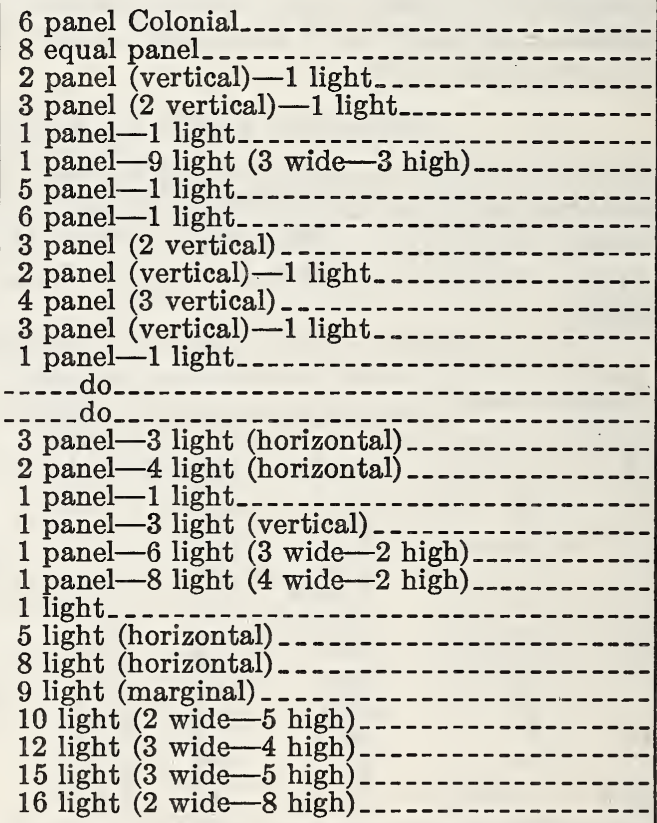 & $\begin{array}{l}12 \\
11 \\
14 \\
14 \\
15 \\
15 \\
16 \\
16 \\
17 \\
17 \\
17 \\
17 \\
15 \\
16 \\
19 \\
20 \\
19 \\
18 \\
18 \\
18 \\
18 \\
23 \\
23 \\
23 \\
23 \\
24 \\
24 \\
24 \\
24\end{array}$ \\
\hline
\end{tabular}

Side Lights

F035

F0535

F0635M
1 light.

25

5 light

6 light (marginal) 
"USE" CLASSIFICATION INDEX-Continued

INTERIOR DOORS

\begin{tabular}{|c|c|c|}
\hline Stock number & Description & Page \\
\hline 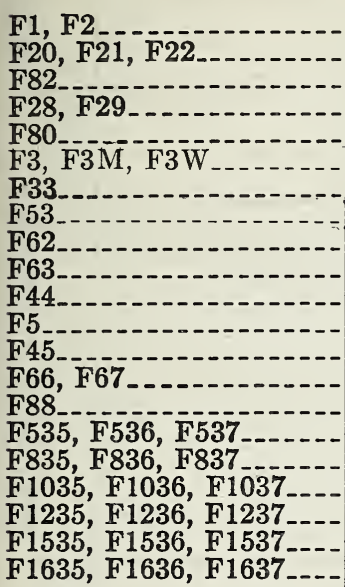 & 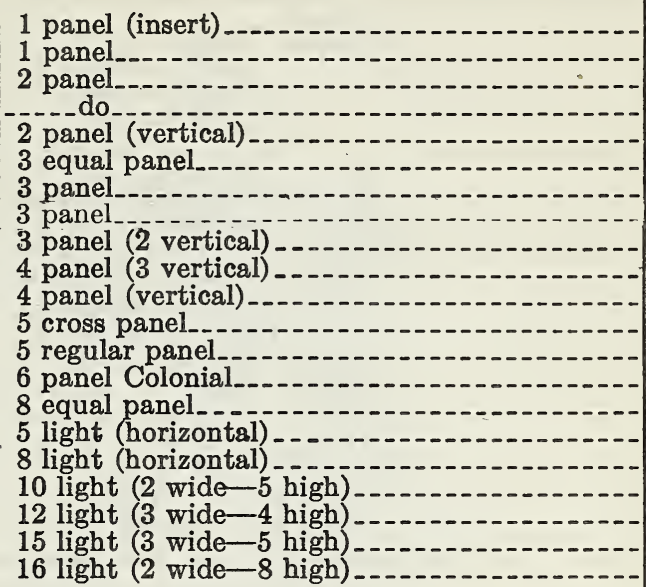 & $\begin{array}{l}11 \\
11 \\
15 \\
16 \\
11 \\
13 \\
13 \\
12 \\
17 \\
17 \\
14 \\
12 \\
14 \\
12 \\
11 \\
23 \\
23 \\
24 \\
24 \\
24 \\
24\end{array}$ \\
\hline
\end{tabular}

\section{Riar Entrance Doors}

F13, F13M, F13W
F133
F128, F109 F129
F147
F182
F1142
F415
F415H
F453
F214
F214H
F117
F1171/2
F118
F1181/2
F318
F418
F618
F918

2 panel-1 light_....... 13

13

1 panel-1 light.

16

19

1 panel-9 light (3 wide-3 high) 15

2 panel-1 light_.._._._. 19

2 panel-4 light (2 wide-2 high)

2 panel-4 light (horizontal)

3 panel-4 light (2 wide-2 high)

2 panel-4 light (2 wide-2 high)

3 pant-1 light_........ 20

3 panel-3 light (horizontal)

4 panel-1 light................... 20

5 panel-1 light.... 20

3 panel-1 light... 21

4 panel-1 light_.. 21

3 panel-3 light (vertical)

3 panel-4 light (vertical)

3 panel-6 light (3 wide-2 high)

3 panel-9 light (3 wide-3 high) 22

\section{StorM Doors}

\begin{tabular}{l|l|l|l}
\hline FS7 & 7 panel & & 25 \\
FS07_. & & & \\
\hline
\end{tabular}


"USE" CLASSIFICATION INDEX-Continued CUpboard Doors

\begin{tabular}{|c|c|c|}
\hline Stock number & Description & Page \\
\hline $\begin{array}{l}\text { F05 } \\
\text { F020 }\end{array}$ & $\begin{array}{l}\text { Cross panel- } \\
1 \text { panel } \\
2 \text { panel }\end{array}$ & $\begin{array}{l}26 \\
26 \\
26\end{array}$ \\
\hline
\end{tabular}

Garage Doors

F491
F691
F693
F495
F495
F696
F894
F093
F199
F290

Saw-buck -4 light

Saw-buck-6 light

2 panel (vertical) - 4 light

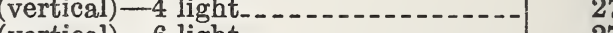

3 panel (vertical) -6 light_..._...........- 27

4 cross panel-4 light_._._. 27

4 cross panel-6 light....... 27

4 panel -4 light._. 28

6 panel-6 light...... 28

4 panel-8 light_... 28

6 panel (vertical)

9 panel (vertical)

Flush door-1 light._............ 29

Flush door-2 light... 29

\section{STOCK NUMBER INDEX}

\section{HOUSE DOORS}

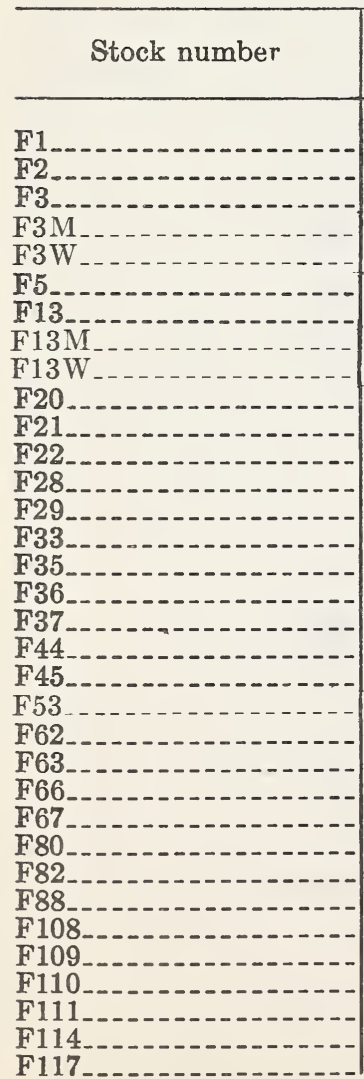

\begin{tabular}{|c|c|}
\hline Description & Page \\
\hline 1 panel (insert) & 11 \\
\hline 3 panel & 13 \\
\hline 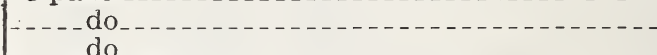 & 13 \\
\hline 5 cross panel & $\begin{array}{l}13 \\
12\end{array}$ \\
\hline 2 panel - 1 light. & 13 \\
\hline- do $_{-\ldots} \ldots$ & $\begin{array}{l}13 \\
13\end{array}$ \\
\hline 1 panel $\ldots . . .$. & 11 \\
\hline 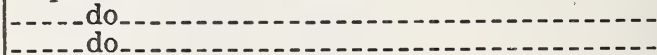 & $\begin{array}{l}11 \\
11\end{array}$ \\
\hline 2 panel & 16 \\
\hline 3 panel-...... & 16 \\
\hline 1 light............. & \\
\hline - & \\
\hline 4 panel (vertical) & 18 \\
\hline 5 panel (4 vertical) & 18 \\
\hline 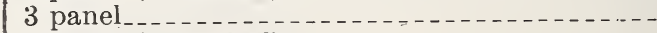 & \\
\hline 3 panel (2 vertical) & \\
\hline $\begin{array}{l}4 \text { panel (3 vertical) } \\
6 \text { panel Colonial }\end{array}$ & \\
\hline 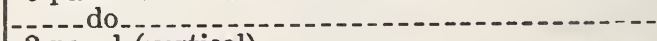 & \\
\hline 2 panel (vertical) & 1 \\
\hline 8 panel 8 panel & 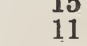 \\
\hline 1 panel-1 light. & 1 \\
\hline - do do & 18 \\
\hline do_-..- & \\
\hline-1 ligh & 19 \\
\hline 1 linh & \\
\hline
\end{tabular}


STOCK NUMBER INDEX-Continued

House Doors-Continued

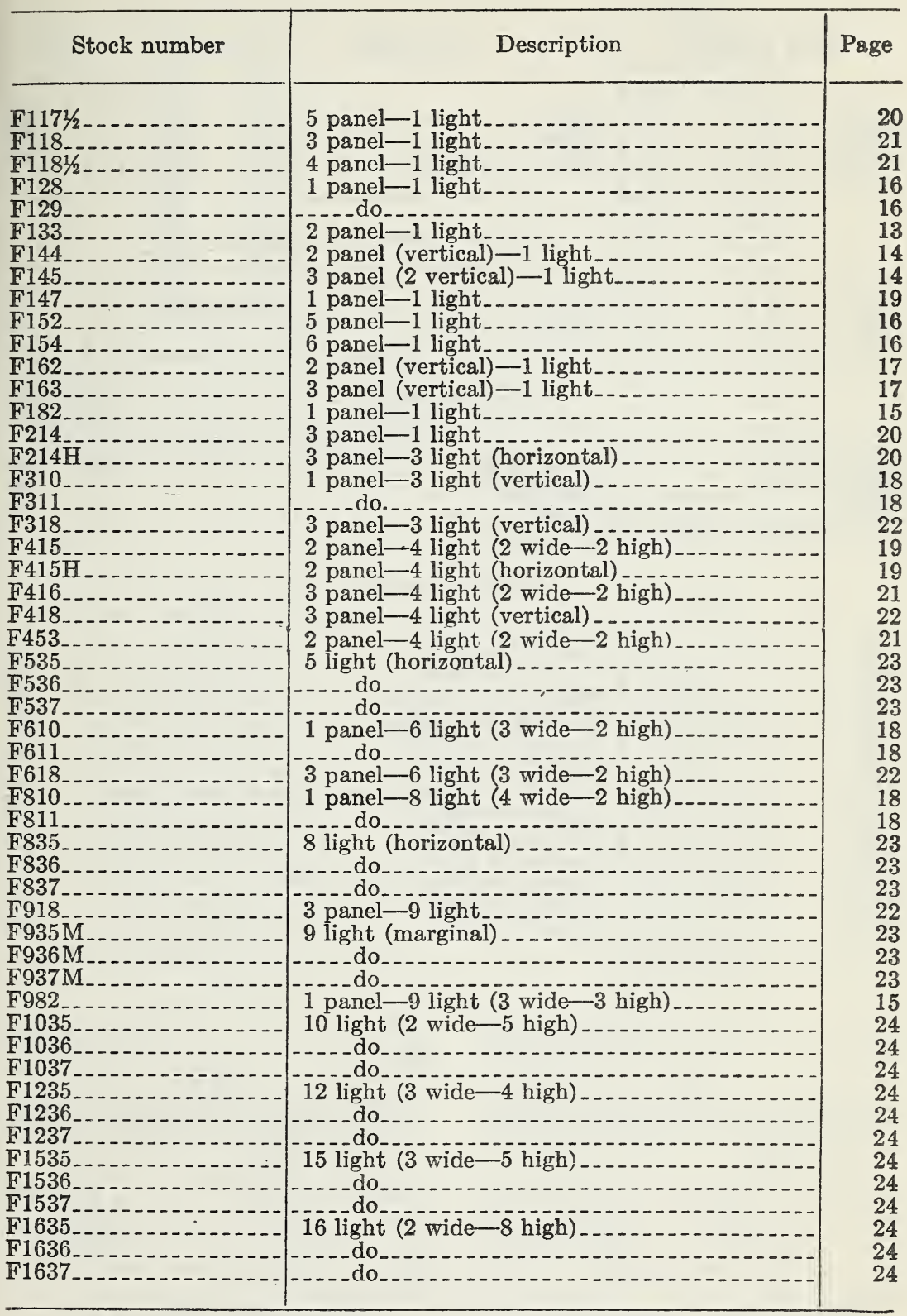




\section{STOCK NUMBER INDEX-Continued}

\section{SIDE Lights}

\begin{tabular}{|c|c|c|}
\hline Stock number & Description & Page \\
\hline $\begin{array}{l}\text { F035 } \\
\text { F0535 }\end{array}$ & $\begin{array}{l}1 \text { light. } \\
5 \text { light } t \text { light (marginal) } \\
6 \text { lon }\end{array}$ & $\begin{array}{l}25 \\
25 \\
25\end{array}$ \\
\hline
\end{tabular}

Storm Doors

\begin{tabular}{|c|c|}
\hline $\begin{array}{l}\text { FS07 } \\
\text { FS7 }\end{array}$ & $\begin{array}{l}5 \text { panel-1 light. } \\
7 \text { panel }\end{array}$ \\
\hline
\end{tabular}

CUPBOARD Doors

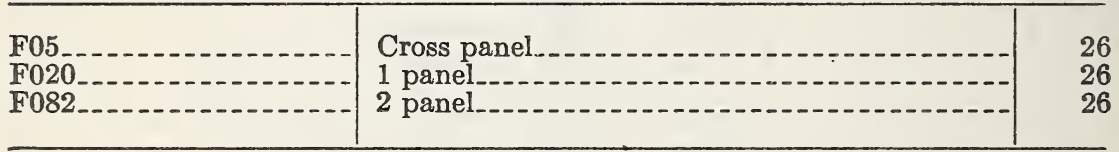

\section{Garagm Doors}

\begin{tabular}{|c|c|c|}
\hline F093 & 6 panel (vertical) & 29 \\
\hline F099_ & 9 panel (vertical) & 29 \\
\hline F190 & Flush door-1 light.... & 29 \\
\hline $\mathrm{F} 290$ & Flush door-2 light..... & 29 \\
\hline F491_. & Saw-buck -4 light & 26 \\
\hline F493. & 2 panel-4 light. & 27 \\
\hline F495. & 4 panel (horizontal) -4 light & 27 \\
\hline F496. & 4 panel-4 light & 28 \\
\hline F691. & Saw-buck-6 light_...... & 26 \\
\hline F693. & 3 panel-6 light & 27 \\
\hline F695 & 4 panel (horizontal) -6 light & 27 \\
\hline F696 & 6 panel-6 light & 28 \\
\hline F894_. & 4. panel-8 light_. & 28 \\
\hline
\end{tabular}

FI

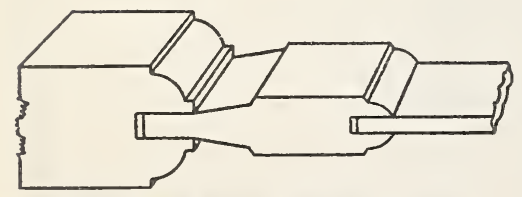

Raised insert frame. Sticking: Ovolo.

.




\section{HOUSE DOORS}

FI

F 2

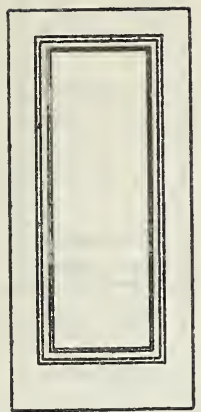

Stiles and top rail

$4 \% 11$

Bottom rail

Insert frame

3-ply laminated flat panel. Furnished in grades $A$ and $B$ only.

F 80

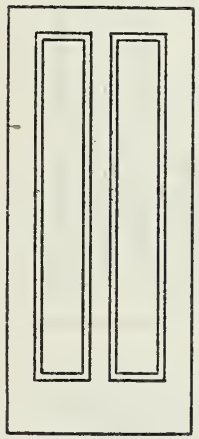

Etiles and top rail

$4910^{\prime \prime \prime}$ Muntin Bottom rai

3-ply laminated flat panels. Can also be fur. nished with raised panels, if desired. Furnished in grades $A$ and $B$ only. Sticking: Standard.

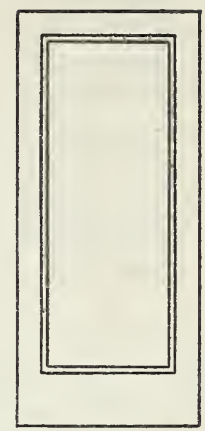

F20 F21 F22

Stiles.

Top rail Bottom rail-_... $938^{\prime \prime} 1138^{\prime \prime} 1138^{\prime \prime}$

3-ply tamingted flat panel. Furnished in grades $A$ and $B$ only. Sticking: Standard.

\section{F88}

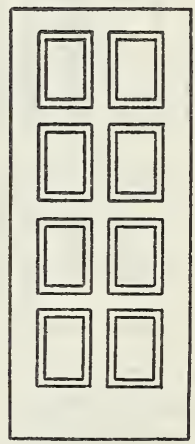

Stiles and top rail Intermediate rails and muntins........... 27/8" Bottom rail. ............................... 938"

3-ply laminated flat panels. Can also be furnished with raised panels, if desired. Furnishod in grades $A$ and $B$ only. Sticking: Standard. 
F5

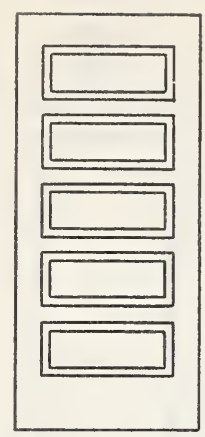

Stiles and top rail

Intermediate rails_........................ $412^{\prime \prime}$

Bottom rail ...................................

8-ply laminated flat panels. Can also be furnished with raised panels, if desired. Furnished in grades $A, B$, and $C$ and $138^{\prime \prime}$ millrun. Sticking: standard.

\section{F 66}

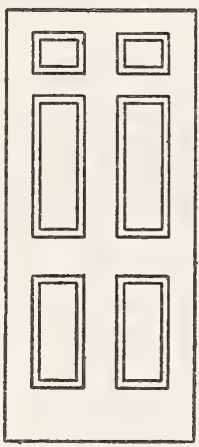

Stiles and top rsil

Iock rail

Intermediate rail and muntins

Bottom rail.

Hoight from floor to top of lock rail ...... 361/2" Height from top of intermediate rail to top of door

Eoight of center panels vary with height of door.

Doors 1' 8" and narrower made one panel wide. 3-ply laminated flat panels. Can also be furnished with raised panels, if desired. Furnished in grades $A$ and $B$ only. Sticking: standard.
F 53

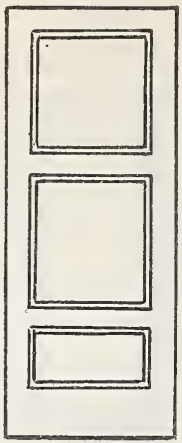

Stiles and top rail rails Bottom rail ........................... 93,

3-ply laminated flat panels. Furnished in grades $A$ and $B$ only. Sticking: Standard.

\section{F 67}

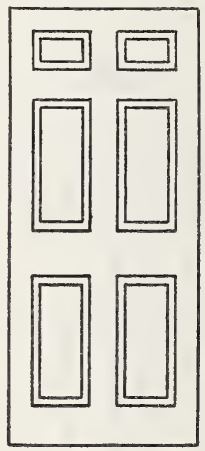

Stiles and top rail ...................... $49 / 6^{\prime \prime}$ Lock rail Intermediate rail and muntins........... $412^{\prime \prime}$

Bottom rail - $7151 \mathrm{~s}^{\prime \prime}$ Height from floor to top of lock rail ....... 411/10" Height from top of intermediate rail to top of door .............................. 125/10 Beight of center panels vary with height of door.

Doors $1^{\prime} 8^{\prime \prime}$ and narrower made one panel wide. 3.ply laminated fiat panels. Can also be furnished with raised panels, if desired. Furnished in grades $A$ and $B$ only. Sticking: Standard. 


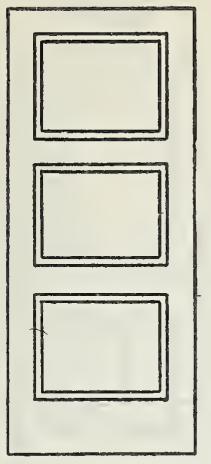

\section{F 3 \\ F 3M \\ F $3 W$}

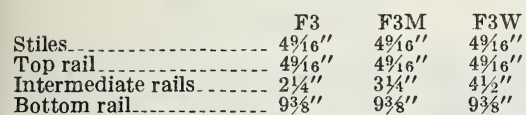

3-ply laminated flat panels. Furnished in grades $A$ and $B$ only. Sticking: Standard.

F 33

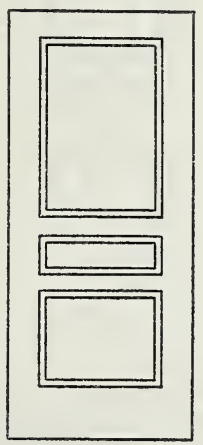

Stiles and top rail

$49 / 6^{\prime \prime}$

Intermediate rails........................... $412^{\prime \prime}$ Bottom rail

3-ply laminated flat panels. Furnished in grades $A$ and $B$ only. Sticking: Standard.
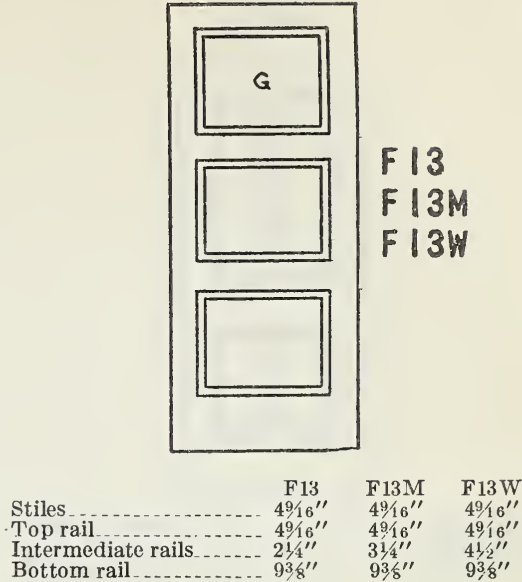

3-ply laminated flat panels. Furnished in grades $A$ and $B$ only. Sticking: Standard.

\begin{tabular}{|c|c|}
\hline $\begin{array}{l}\text { Size of door (same } \\
\text { for } 3 \text { designs) } \\
2^{\prime} 6^{\prime \prime} \times 6^{\prime} 6^{\prime \prime} \\
2^{\prime} 8^{\prime \prime} \times 6^{\prime} 8^{\prime \prime} \\
2^{\prime} 10^{\prime \prime} \times 6^{\prime} 10^{\prime \prime} \\
3^{\prime} 0^{\prime \prime} \times 7^{\prime} 0^{\prime \prime}\end{array}$ & 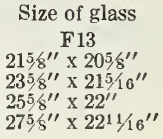 \\
\hline 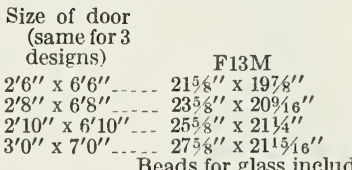 & $\begin{array}{l}\text { Size of glass } \\
\text { F } 13 W \\
2158^{\prime \prime} \times 20^{7} / 16^{\prime \prime} \\
2358^{\prime \prime} \times 211 / 8^{\prime \prime} \\
255,8^{\prime \prime} \times 211316^{\prime \prime} \\
2758^{\prime \prime} \times 22716^{\prime \prime}\end{array}$ \\
\hline
\end{tabular}

F 133

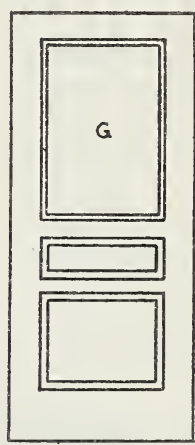

Stiles and top rail ........................ $491 \mathrm{~d}^{p}$ Intermediate rails......................... 416"

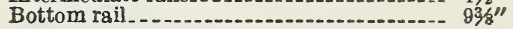

3-ply laminated flat panels. Furnished in grades $A$ and $B$ only. Sticking: Standard.

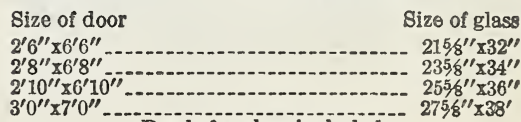

Beads for glass included. 


\section{F 44}

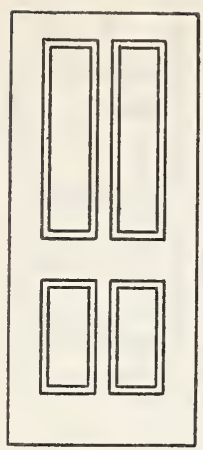

Stiles and top rail

Lock rail

Muntins.

Bottom rail

to top of lock rail

3-ply laminated flat panels. Can also be furnished with raised panels, if desired. Furnished In grades $A$ and $B$ only. Sticking: Standard.

\section{F 45}

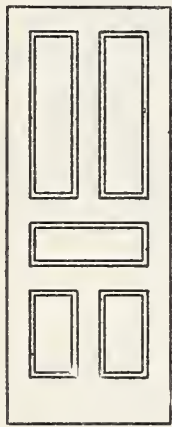

Stiles and tou rail.

Intermediate rails and muntins

Bottom rail

3-ply laminated flat panels. Can also be furalshed with raised panels, if desired. Furnished in grades $A$ and $B$ only. Sticking: Standard.
F 144

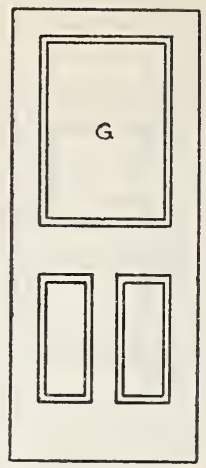

Stiles and top rail

Lock rail

$41 / 2 "$

3-ply laminated flat panels. Can also be furnished with raised panels, if desired. Furnished in grades $A$ and $B$ only. Sticking: Standard.

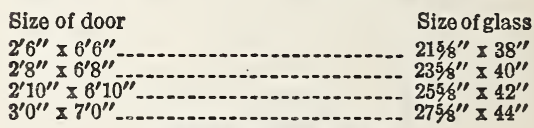

Beads for glass included.

$F 145$

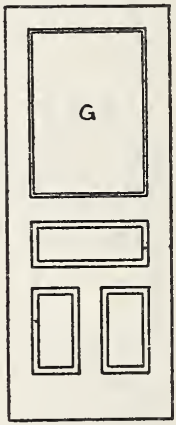

Stiles and top rail Intermediate rails and muntin Bottom rail . . . .

3-ply lawinated flat panels. Can also be furnished with raised panels, if desired. Furnished in grades $A$ and $B$ only. Sticking: Standard.

Size of door

$2^{\prime} 6^{\prime \prime}$ × $6^{\prime} 6^{\prime \prime}$

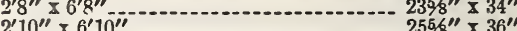

$3^{\prime} 0^{\prime \prime} \times 7^{\prime} 0^{\prime \prime} \ldots$

Beads for glass included. 


\section{F 82}

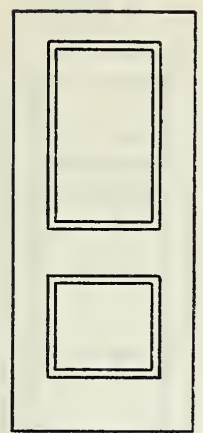

8tiles and top rail Lock rail

Bottom rail -

Height to ton of lock rail.

3-ply laminated flat panels. Furnished in grades $A$ and $B$ only. Sticking: Standard.

\section{F 982}

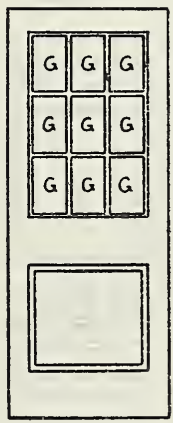

Stlles and top rail

Lock rail.-

- 4\%"

$8 \%$

Bars 1/2" between glass. 3-ply laminated flat panel. Furnished in grades $A$ and $B$ only. Sticking: Standard.

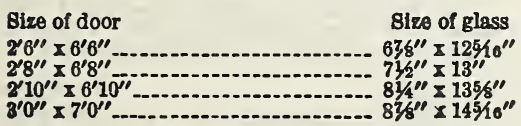

Beads for glass included.

$5399070-43-3$
F 182

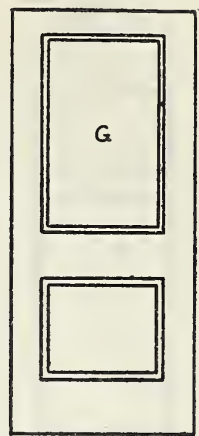

Stiles and top rail

Lock rail.

Bottom rail $A$ and $B$ only. Sticking: Standard.

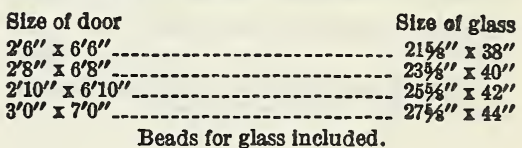

F 108

F 109
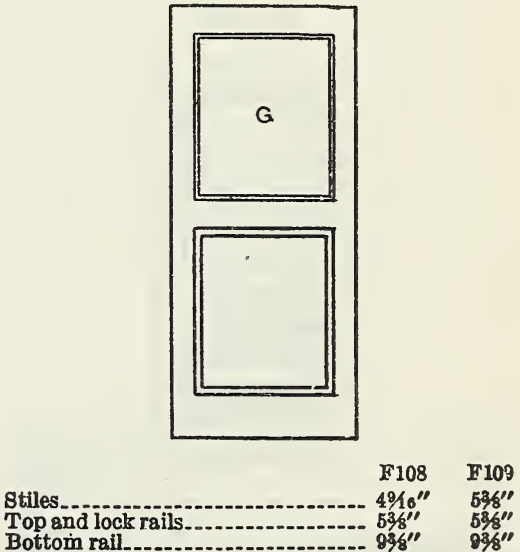

3-ply laminated flat panels. Furnished in grades $A$ and $B$ only. Sticking: Standard.

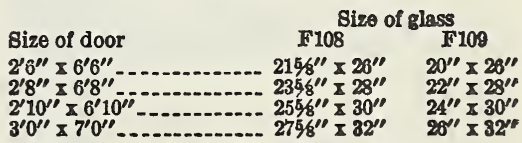

Beads for glass included. 
$F 28$

F29

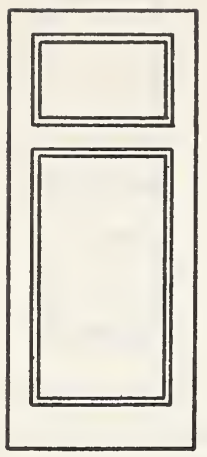

8tiles and top rall

Look rail

Bottom rail

Height from top of lock rail to top of door.

8-ply lanainated flat panels. Furnished in grades $A$ and $B$ only. Sticking: Standard.

\section{F28}

$4 \% 0^{\prime \prime}$ $412^{\prime \prime}$ 93."
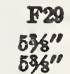
58, $222^{\prime \prime} \quad 22 \% "$

\section{F 152}

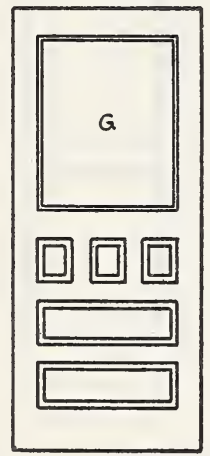

Stiles

Top and lock rails

Intermediato rails and muntins Bottom rail

4\%"1" $538^{\prime \prime}$ $338^{\prime \prime}$

3-ply laminated flat panels. Can also be furnished with raised panels, if desired. Furnished in grades $A$ and $B$ only. Sîticking: Standard.

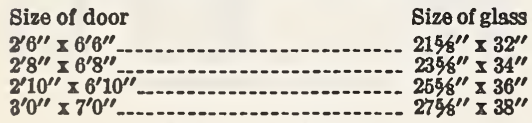

Beads for glass included.
F 128

F 129
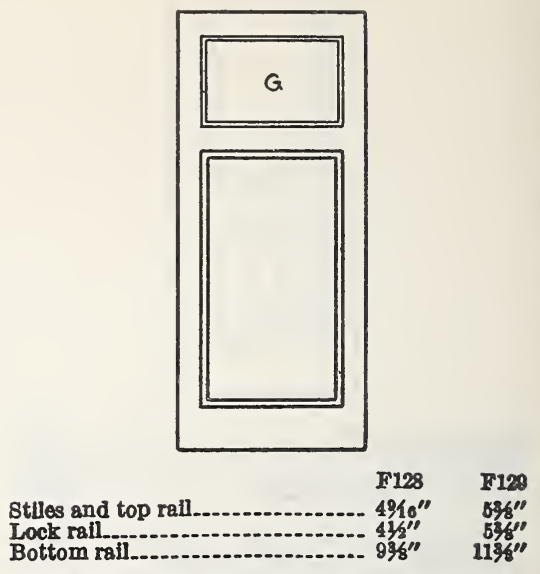

3-ply laminated flat panels. Furnished in grades $A$ and $B$ only. Sticking: Standard.

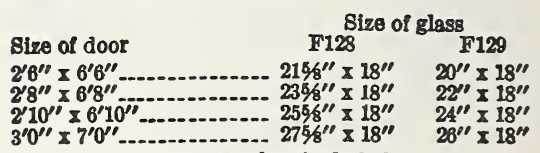

Beads for glass included.
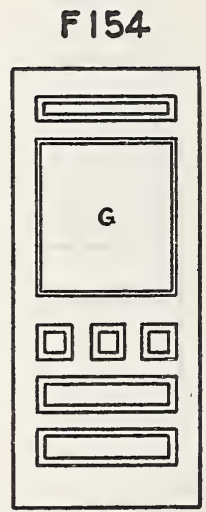

Stiles

and lock rails

Intermediate rails and muntins........ $338^{\prime \prime}$

Bottom rall. . . . .

3-ply laminated flat panels. Can also be furnished with raised panels, if desired. Furnished in grades $A$ and $B$ only. Sticking: Standard.

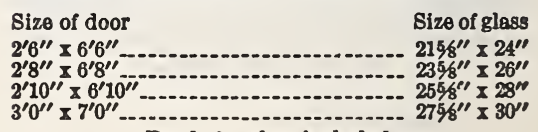

Beads for glass included. 
F62

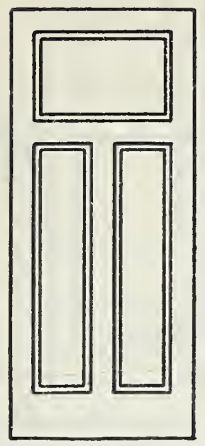

stiles and top rail.

Lock rail and muntin

Bottom rail

Height from top of lock rail to top of door.

3-ply lsminated fiat panels. Furnishod in grades $A$ fand $B$ only. Sticking: Standard.

\section{F63}

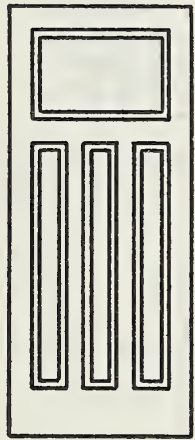

8tiles and top rail

Lock rail

Muntins .

Height from top of lock rail to top of door

8-ply laminated flat panels. Furnished in grades $A$ and $B$ only. Sticking: Standard.
F 162

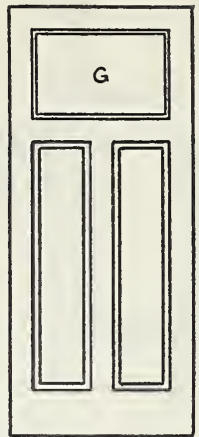

Stiles and top rail

Lock rail and muntin

4911 Lock rail and

3-ply laminated fiat panels. Oan also be furntshed with raised panels, if desired. Fornished in grades $A$ and $B$ only. Sticking: Standard.

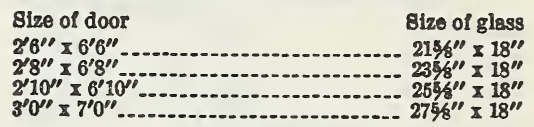

Beads for glass included.

\section{F 163}

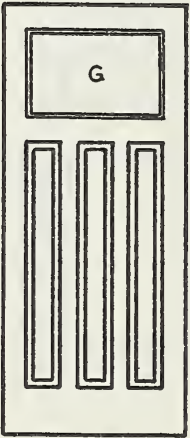

stiles and top rail

Lock rail

Muntins.

Bottom rail

3-ply laminated fiat panels. Can also be furnished with raised panels, if desired. Furnished in grades $A$ and $B$ only. Sticking: Standard.

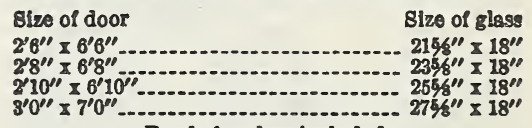

Beads for glass included. 

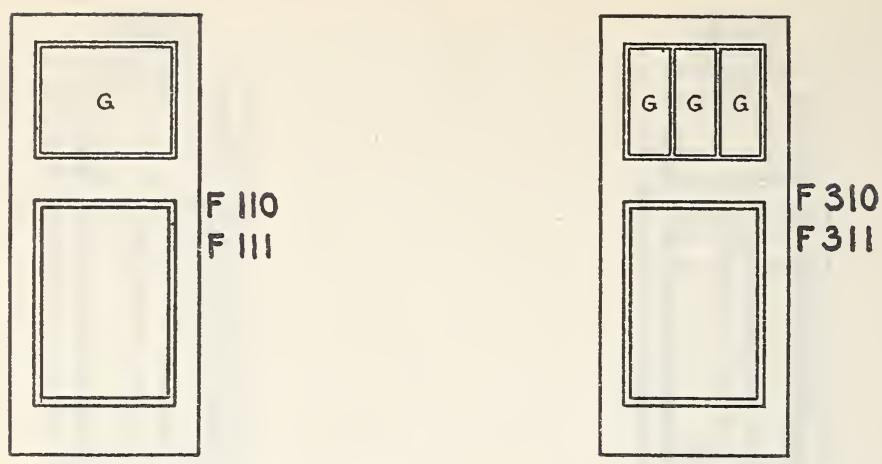

F110 F111

F310 F311

Stiles

$4 \% 6^{\prime \prime}$

Top rail

$538^{\prime \prime}$

Lock rail

Bottom rail _..................... 938 "

$5 \% "$ 586

3-ply laminated flat panel. Furnished in gradiss $A$ and $B$ only. Sticking: Standard.

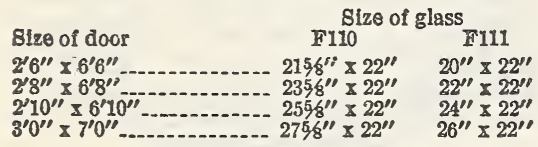

Beads for glass included.

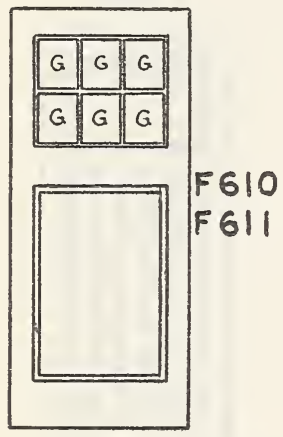

F610 F611

Stiles

$4 \% 10^{n}$

Top rail

$538^{\prime \prime}$

Lock rall.

$8^{\prime \prime}$

938"

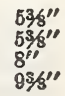

Bers 1/2" between glass. 3-ply laminated fist panel. Furnished in grades $A$ and $B$ only. Sticking: Standard.

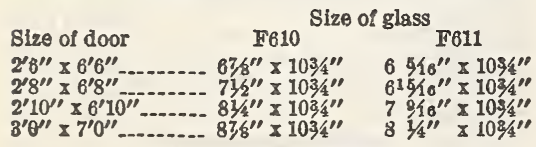

Beads for glass included.

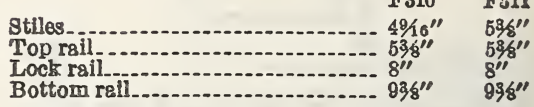

Bars 32" between glass. 3-ply lamingted flat panel. Furnished in grades $A$ and $B$ only. Bticking: Standard.

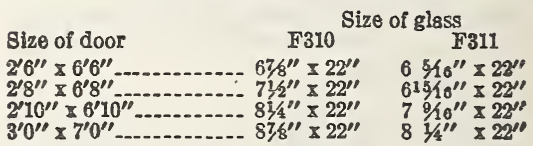

Beads for glass included.
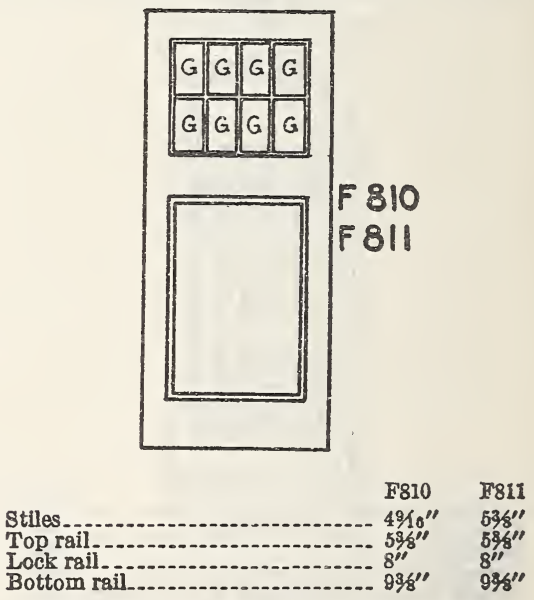

Bars 1/2" between glass. 3-ply laminated flat panol. Furnished in grades $A$ and $B$ only. Sticking: Standard.

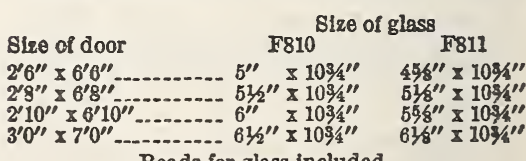

Beads for glass included. 


\section{F 147}

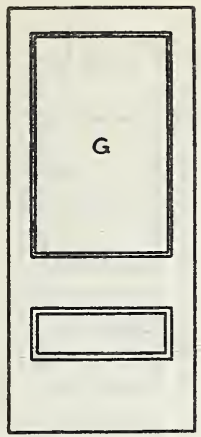

Stiles and top rail.

Lock rail.

Bottom rail. laminated flat panel. Can also be furnished with raised panel, if desired. Furnished in grades $A_{\llcorner}$and $B$ only. Sticking: Standard.

\section{Size of door}

$2^{\prime \prime} 8^{\prime \prime} \times 6^{\prime} 8^{\prime \prime}$

$2^{\prime} 10^{\prime \prime \prime}$ × $610^{\circ \prime \prime}$

$3^{\prime} 0^{\prime \prime} \times 7^{\prime} 0^{\prime \prime}$

Beads for glass included.

F415

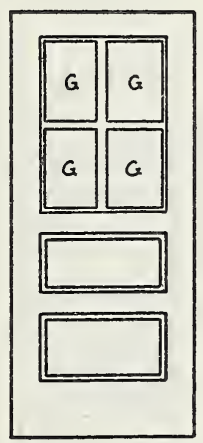

8tiles and top rail.

$4 \% 16^{\prime \prime}$ Lock and intermediate rails

Size of glass $22^{\prime \prime} \times 46^{\prime \prime}$ $24^{\prime \prime} \times 48^{\prime \prime}$ $28^{\prime \prime} \times 50^{\prime \prime}$

538 938, fur. nished with raised panels, if desired. Furnished
in grades $A, B$, and $C$. Sticking: Standard.

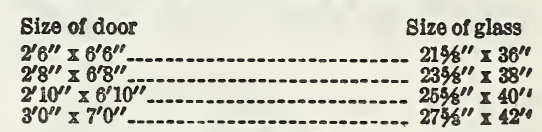
Beads for glass included.

\section{F $415 \mathrm{H}$}

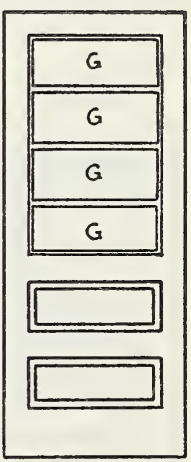

Stiles and top rail ...................... 4 y $16^{\prime \prime}$ Lock and intermediate rails

Bars 1/2" between glass. 3-ply laminated flat panels. Can also be furnished with raised panels, if desired. Furnished in grades $A$ and $B$ only. Sticking: Standard.

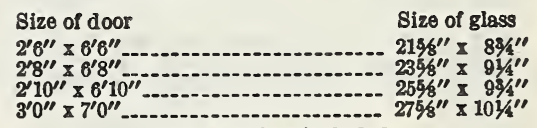
Beads for glass included.
Bars 1/2" between glass. 3-ply laminated flat panels. Can also be furnished with raised panels, if desired. Furnished in grades $A, B$, and $C$. Sticking: Standard.

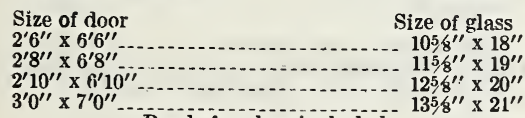

Size of glass $1058^{\prime \prime} \times 18^{\prime \prime}$ $1158^{\prime \prime} \times 19^{\prime \prime}$ $1258^{\prime \prime} \times 20^{\prime \prime}$ $3^{\prime} 0^{\prime \prime} \times 7^{\prime} 0^{\prime \prime}$ Beads for glass included.
F 114

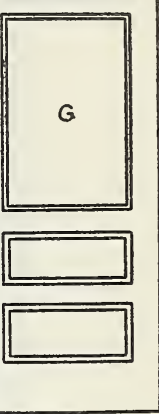

Stiles and top rail

Intermed

$4 \% 10^{\prime \prime}$

$9 \% 8^{\prime \prime}$

3-ply laminated fist panels. Oan also be fur.

(a)




\section{$F 214$ \\ FII9 (5X PANEL LAYOUT)}

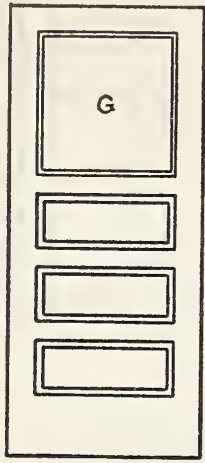

8tiles and top rail.

Lock and intermediate rail

Bottom rail

3-ply laminated flat panels. Can also be furnished with raised panels, if desired. Furnished in grades $A, B, C$, and $138^{\prime \prime}$ millrun. Sticking: Standard.

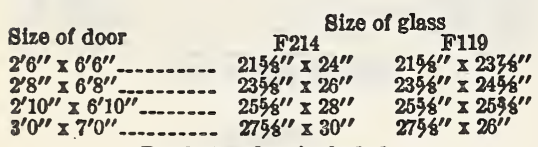

Beads for glass included.

\section{$\mathrm{F} 214 \mathrm{H}$}

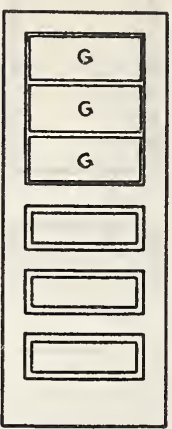

Stiles and top rail

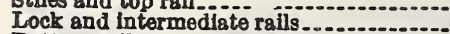
Bottorn rail

Bars 1/2" between glass. 3-ply lamingted flat panels. Oan also be furnished with raised panels, if desired. Furnished in grades $A$ and $B$.only. Sticking: Standard.

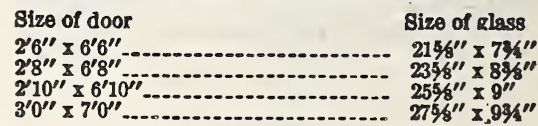

Beads for glass included.
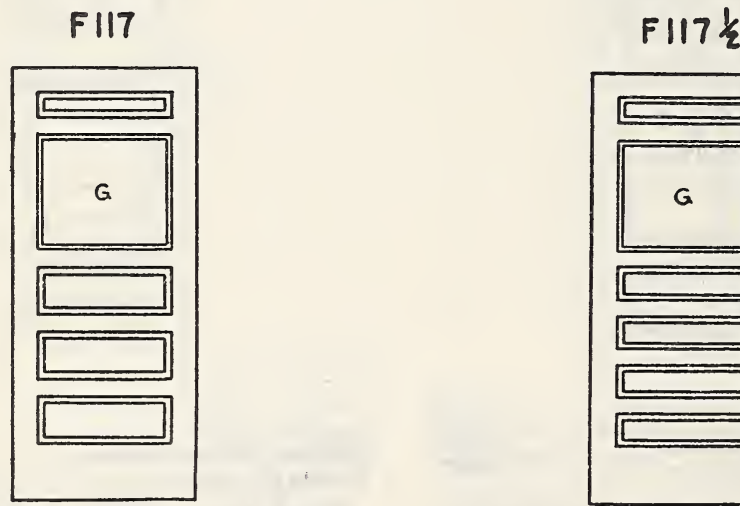

8 tiles

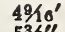

Top and lock rails 98,

Bottom rall

3-ply laminated fiat panels. Can also be furnished with raised panels, if desired. Furnished in grades $A, B, C$, and $138^{\prime \prime}$ millrun. Sticking Standard.

Size of door

Size of glass

$266^{\prime \prime} \times 6^{\prime} 6^{\prime \prime}$

$2^{\prime \prime \prime} \times 6^{\prime \prime} 8^{\prime \prime}$

$210^{\prime \prime} \times 6^{\prime} 10^{\prime \prime}$ $2158^{\prime \prime} \times 24^{\prime \prime}$ $238^{\prime \prime} \times 26^{\prime \prime}$ $25 \% 8^{\prime \prime} \times 28^{\prime \prime}$ $278^{\prime \prime} \times 30^{\prime \prime}$

Beads for glass included.

\section{Fil}

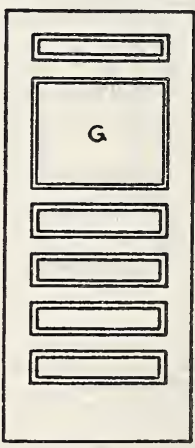

Stiles.

Intermediate rails

Bottom rail

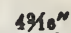

3-ply laminated fiat panels. Can 5 also be fur nished with raised panels, if desired. Furnished in grades $A, B$, and $C$. Sticking: standard.

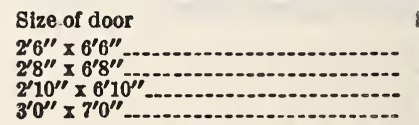

Eive of glass $213811 \times 22^{\prime \prime}$ $233^{\prime \prime} \times 2 \mathrm{~s}^{\prime \prime}$ $25861 \times 280$ 27 C." $^{\prime \prime} \times 2^{\circ}$
Top and lock rails 
F 416

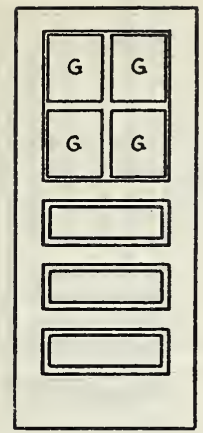

Stiles and top rail. Lock rail

Intermediate rails

$4916^{\prime \prime}$

Bottom rail . . . . . . . . .

Bars 1/2" between glass. 3-ply laminated flat panels. Can also be furnished with raised panels if desired. Furnished in grades $A, B$, and $C$. Sticking: Standard.

Size of door

$2^{\prime} 6^{\prime \prime} \times 6^{\prime} 6^{\prime \prime}$

(15.

× $6^{\prime} 10^{\prime \prime}$ $3^{\prime} 0^{\prime \prime} \times 7^{\prime} 0^{\prime \prime} \ldots \ldots \ldots \ldots$

Beads for glass included.

\section{F 118}

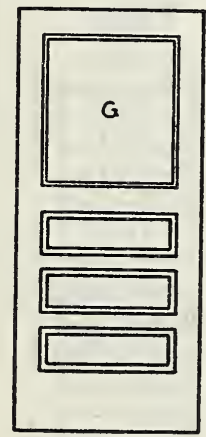

Stiles 49

Top and lock rails

Intermediste rails.

Bottom rail

3-ply laminated flat panels. Can also be furnished with raised panels, if desired. Furnished in grades $A, B, C$, and $138^{\prime \prime}$ millrun. Sticking: Standard.

Beads for glass included
Size of $2356^{\prime \prime} \times 34^{\prime \prime}$ $2556^{\prime \prime} \times 36^{\prime \prime}$ $2758^{\prime \prime} \times 38^{\prime \prime}$
$\mathbf{F} 453$

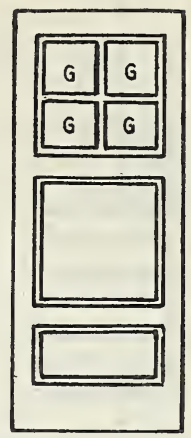

Stiles and top rail $4916^{\prime \prime}$ Intermediate rails ........................... Bottom rail ................ $938^{\prime \prime}$

Bars 1/2" between glass. 3-ply laminated flat panels. Furnished in grades $A$ and $B$ only. Sticking: Standard.

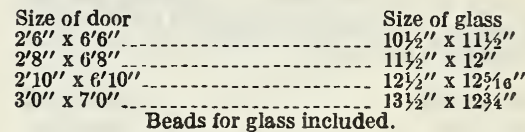

F $118 \frac{1}{2}$

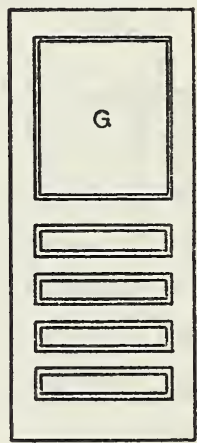

Stiles. $4 \%$

Top and lock rails

Intermediate rails ...................... $388^{\prime \prime}$

Bottom roil............... 98\%

3-ply laminated flat panels. Can also be furnished with raised panels, if desired. Furnished in grades $A, B$, and $C$. Sticking: Standard.

Size of door $2158^{\prime \prime} \times 30^{\prime \prime}$ $28 \times 6^{\prime \prime \prime} 8^{\prime \prime} \ldots . . . . .-2356^{\prime \prime} \times 32^{\prime \prime}$

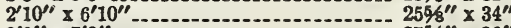
$3^{\prime} 0^{\prime \prime} \times 7^{\prime} 0^{\prime \prime} \ldots$ Beads for glass included. 


\section{F 318}

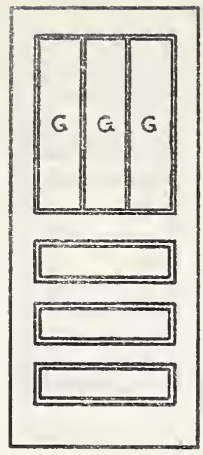

Stlles.

Top and lock rails

Incermediate rails $4910^{\prime \prime}$ $538^{\circ \prime \prime}$

Botsom ratl

Bars 1/2" between glass. 3-ply laminated flat panels. Can also be furnished with raised panels, if desired. Furnished in grades $A, B$, and $C$. Sticking: Standard.

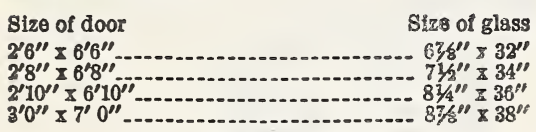

Beads for glass included.

F 618

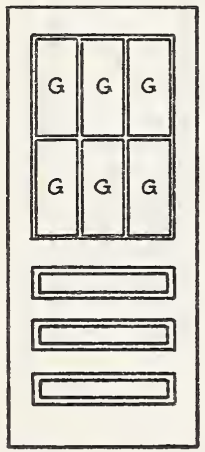

Stilles.

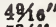

Top and lock rails

Intermediate rails

Bottom rail

Bars 1/2" between glass. 3-ply laminated flat panels. Can also be furnished with raised panels, if desired. Furnished in grades $A, B$, and $C$. Sticking: Standard.

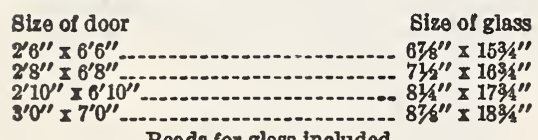

Beads for glass included.
$F 418$

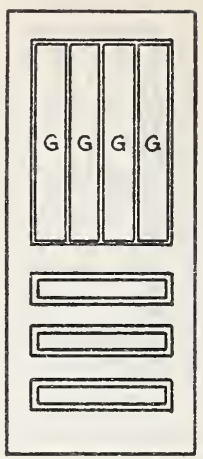

Stĩles

Top and lock rail

Intermediato rails

Bottom rail

Bars "'6" between glass. 3-ply laminated flat panels. Can also be furnished with raised panels, if desired. Furnished in grades $A, B$, and $C$. Sticking: Standard.

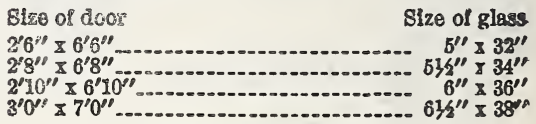

Beads for glass included.

F 918

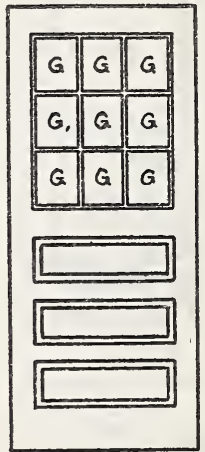

8tilles.

Top and lock rails

Intermediate rails

Bottom rail

Bars 1/2" between glass. 3-ply laminated flat panels. Can also be furnished with raised panels, if desired. Furnished in grades $A, B$, and $C$. Sticking: Standard.

\section{Sine of door \\ $2^{\prime} 6^{\prime \prime}$
$2^{\prime} 8^{\prime \prime} \times 6^{\prime \prime} 6^{\prime \prime} \times 6^{\prime \prime}-$}

Size of glass $628^{\prime \prime} \times 105 \%$ "

$8^{\prime} 0^{\prime \prime} \times 7^{\prime} 0^{\prime \prime}$

Beads for glass included. 


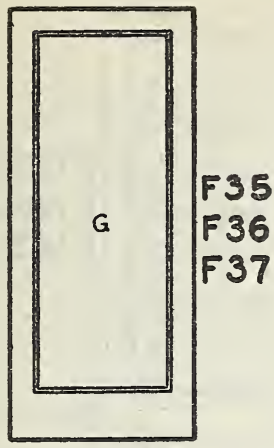

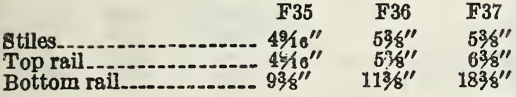

Furnished in grades $A$ and $B$ only. Sticking: Standard.
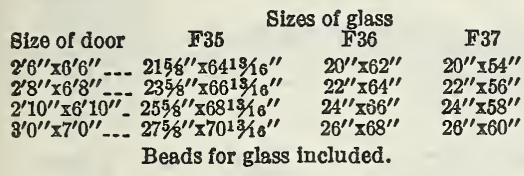
$0211-50^{\prime \prime}$ $24 \times 50^{\prime \prime}$ $24^{\prime \prime} \times 58^{\prime \prime}$ Beads for glass included.

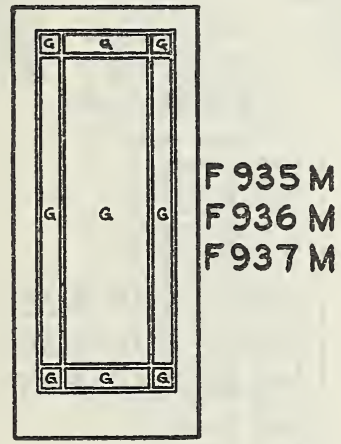

F935M F936M F937M

Stiles.

$496^{\prime \prime} \quad 53 / 8^{\prime \prime} \quad 53 / 8^{\prime \prime}$

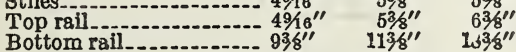

Bars 32" between glass. Furnished in grades $A$ and $B$ only. Sticking: Standard.

\section{Size of door}

$2^{\prime} 8^{\prime \prime} \times 6^{\prime} 8^{\prime \prime}-1-2 \times 5$

$2^{\prime} 10^{\prime \prime} \times 6^{\prime} 10^{\prime \prime}--5 \times 5$

$3^{\prime} 0^{\prime \prime} \times 7^{\prime} 0^{\prime \prime} \ldots 5 \times 3{ }^{\prime \prime}$

$2^{\prime} 6^{\prime \prime} \times 6^{\prime} 6^{\prime \prime}$

$2^{\prime} 8^{\prime \prime} \times 6^{\prime} 8^{\prime \prime}-\ldots-2 \times 5$

$2^{\prime} 10^{\prime \prime} \times 6^{\prime} 10^{\prime \prime}-5 \times 5$

$3^{\prime} 0^{\prime \prime} \times 7^{\prime} 0^{\prime \prime} \cdots 5 \times 5$

Sizes of glass (in inches)

F935M

$\begin{array}{lll}5 \times 533 / 4 & 5 \times 101 / 2 & 101 / 2 \times 533 / 4 \\ 5 \times 553 / 4 & 5 \times 121 / 2 & 1212 \times 5534\end{array}$

$1212 \times 5534$

$5 \times 5934 \quad 5 \times 161 / 2 \quad 161 / 2 \times 5934$

F936M

$5 \times 507 / 8 \quad 5 \times 87,878 \times 8 \times 507 / 8$

$5 \times 5278 \quad 5 \times 107 / 8 \quad 107 / 8 \times 527 / 8$

$5 \times 5478 \quad 5 \times 127 / 8-127 / 8 \times 5478$

$5 \times 567 / 8 \quad 5 \times 147 / 8 \quad 147 / 8 \times 567 / 8$

\section{F937M}

$2^{\prime} 6^{\prime \prime} \times 6^{\prime} 6^{\prime \prime}$

$5 \times 57344 \quad 5 \times 141 / 2-141 / 2 \times 573 / 4$

2

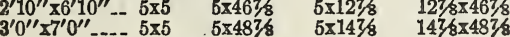

Beads for glass included.
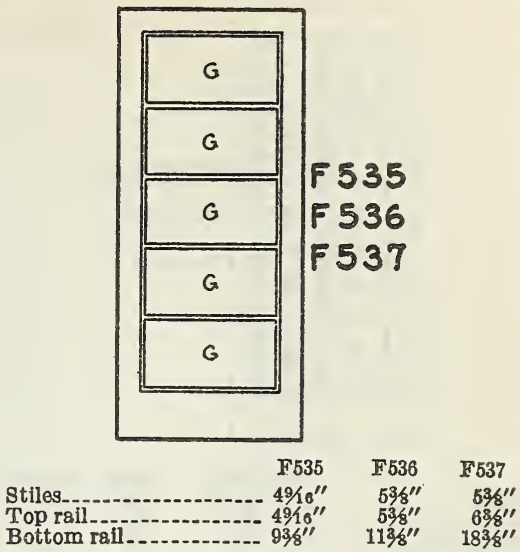

Bars 16" between glass. Furnished in grades $A$ and $B$ only. Sticking: Standard.

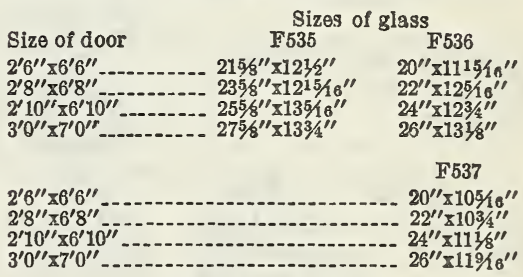

Beads for glass included.
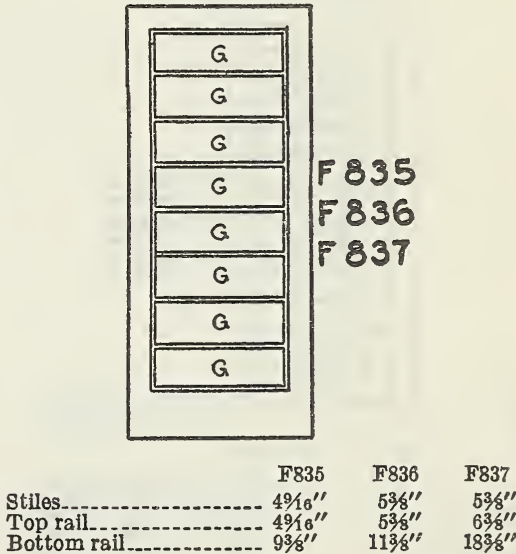

Bottom rail

Bars $1 / 2$ " between glass. Furnished in grades $A$ and $B$ only. Sticking: Standard.

\begin{tabular}{|c|c|c|c|}
\hline \multicolumn{4}{|c|}{ Sizes of glass } \\
\hline Size of door & F835 & F836 & F837 \\
\hline $\begin{array}{l}2^{\prime} 6^{\prime \prime} \times 6^{\prime} 6^{\prime \prime} \\
2^{\prime} 8^{\prime \prime} \times 6^{\prime} 8^{\prime \prime}- \\
2^{\prime} 10^{\prime \prime} \times 6^{\prime} 0^{\prime \prime \prime} \\
3^{\prime} 0^{\prime \prime} \times 7^{\prime} 0^{\prime \prime}\end{array}$ & $\begin{array}{l}2158^{\prime \prime} \times 75 / 8 " \\
2358^{\prime \prime} \times 778^{\prime \prime} \\
2558^{\prime \prime} \times 818^{\prime \prime} \\
2758^{\prime \prime} \times 838^{\prime \prime}\end{array}$ & $\begin{array}{l}20^{\prime \prime} \times 714^{\prime \prime} \\
22^{\prime \prime} \times 712^{\prime \prime} \\
24^{\prime \prime} \times 734^{\prime \prime} \\
26^{\prime \prime} \times 8^{\prime \prime}\end{array}$ & $\begin{array}{l}20^{\prime \prime} \times 61^{\prime \prime} \\
22^{\prime \prime} \times 64^{\prime \prime} \\
24^{\prime \prime} \times 634^{\prime \prime} \\
26^{\prime \prime} \times 7^{\prime \prime}\end{array}$ \\
\hline
\end{tabular}

Beads for glass included. 

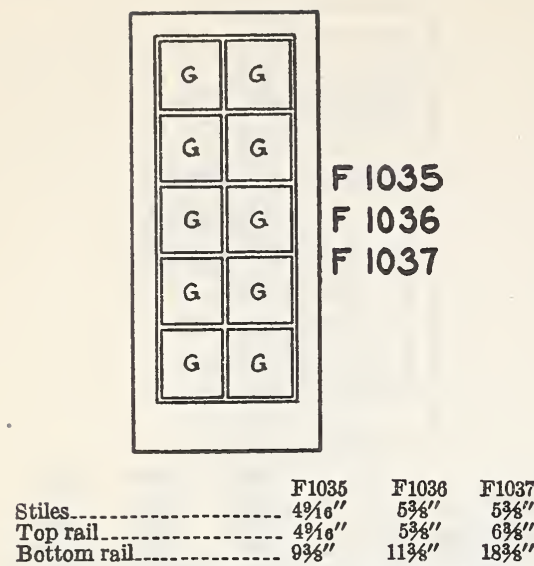

Bars $1 / 2^{\prime \prime}$ between glass. Furnished in grades $A$ and $B$ only. Sticking: Standard.

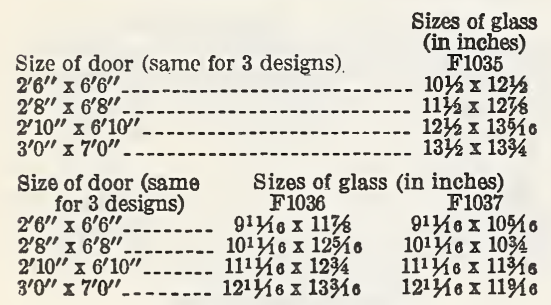

Beads for glass included.

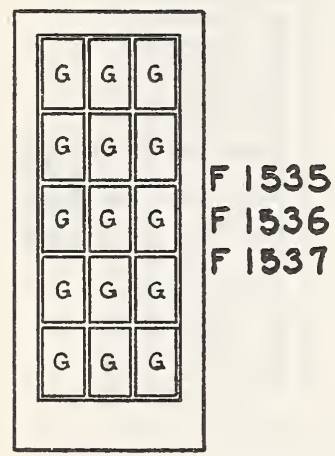

F1535 F1536 F1537

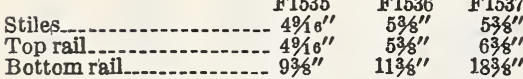

Bars 1/2" between glass. Furnished in grades $A$ and $B$ only. Sticking: Standard.

\begin{tabular}{|c|c|}
\hline $\begin{array}{l}\text { Size of door (same for } 3 \text { designs) } \\
2^{\prime} 6^{\prime \prime} \times 6^{\prime} 6^{\prime \prime} \\
2^{\prime} 8^{\prime \prime} \times 6^{\prime \prime} 8^{\prime \prime} \\
2^{\prime} 10^{\prime \prime} \times 6^{\prime} 10^{\prime \prime} \\
3^{\prime} 0^{\prime \prime} \times 7^{\prime} 0^{\prime \prime}\end{array}$ & $\begin{array}{l}\text { (in inches) } \\
\text { F } 1536 \\
613 / 16 \times 121 / 2 \\
77 / 16 \times 123 / 8 \\
81 / 8 \times 135 / 16 \\
813 / 16 \times 13 \% 4\end{array}$ \\
\hline 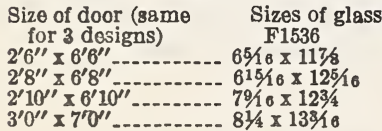 & $\begin{array}{l}\text { (in inches) } \\
\text { F1537 } \\
65 / 16 \times 10 \% / 8 \\
615 / 16 \times 10^{3} / 4 \\
79 / 16 \times 113 / 16 \\
814 \times 11 \% 16\end{array}$ \\
\hline
\end{tabular}
Beads for glass included.
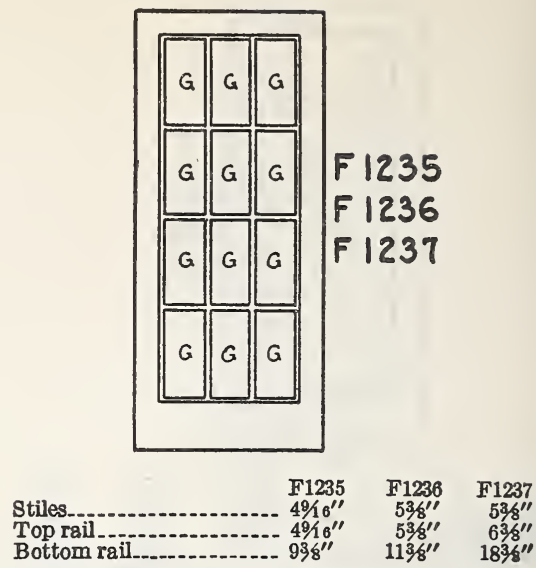

Bars $1 / 2$ " between glass. Furnished in grades $A$ and $B$ only. Sticking: Standard.

\begin{tabular}{|c|}
\hline $\begin{array}{l}\text { Size of door (same for } 3 \text { designs) } \\
2^{\prime} 6^{\prime \prime} \times 6^{\prime} 6^{\prime \prime} \\
2^{\prime} 8^{\prime \prime} \times 6^{\prime} 8^{\prime \prime} \\
2^{\prime} 10^{\prime \prime} \times 6^{\prime} 10^{\prime \prime} \\
3^{\prime} 0^{\prime \prime} \times 7^{\prime} 0^{\prime \prime} \text { (in inches) } \\
\text { F1235 }\end{array}$ \\
\hline
\end{tabular}

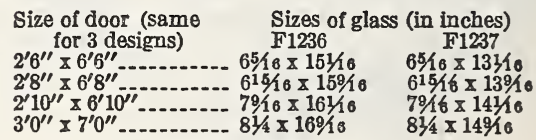
Beads for glass included.
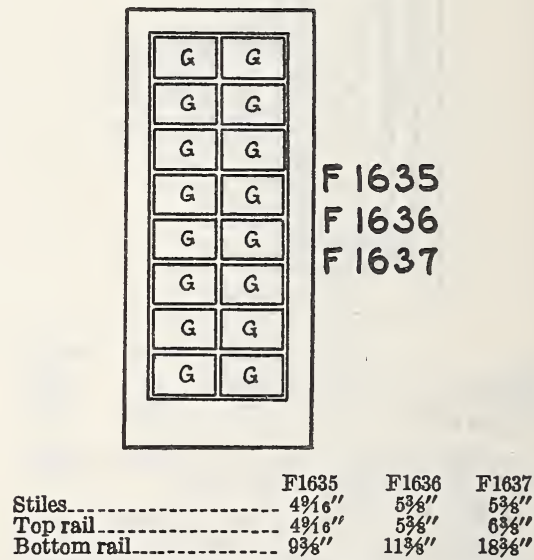

Bars $1 / 2$ " between glass. Furnished in grades $A$ and $B$ only. Sticking: Standard.

ing of

of door (same for 3 designs) F1635

$2^{\prime} 6^{\prime \prime} \times 6^{\prime} 6^{\prime \prime}$ (same $101 / 2 \times 756$ $2^{\prime} 8^{\prime \prime} \times 6^{\prime} 8^{\prime \prime}-112 \times 778$ $2^{\prime} 10^{\prime \prime} \times 6^{\prime} 10^{\prime \prime}-\cdots$ $3^{\prime} 0^{\prime \prime} \times 7^{\prime} 0^{\prime} \ldots \ldots \ldots$

Size of door (same Sizes of glass (in inches) for 3 designs) $\quad$ F1636 $\quad$ F1637 $2^{\prime} 6^{\prime \prime} \times 6^{\prime} 6^{\prime \prime} \ldots \ldots \ldots . . . . .91116 \times 71 / 4 \quad 9^{11} 16 \times 61 / 4$ $2^{\prime} 8^{\prime \prime} \times 6^{\prime} 8^{\prime \prime} \ldots$ $2^{\prime} 10^{\prime \prime} \times 6^{\prime} 10^{\prime \prime} \ldots \ldots$ $3^{\prime} 0^{\prime \prime} \times 7^{\prime} 0^{\prime \prime}-1211 / 16 \times 8 \quad 121116 \times 7$

Beads for glass included. 


\section{SIDELIGHTS}

F035

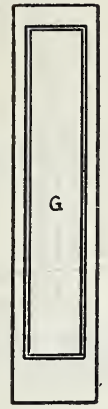

F 0535

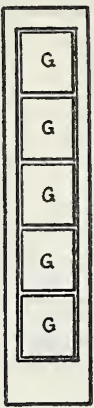

F0635M

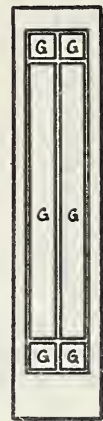

Stiles.

Top rail

Not over 21/2" wide.

Not over $61 / 2^{\prime \prime}$ wide.

Bottom ra

Not over 181/2" wide.

Top and bottom rails made same width as in doors with which they are used. Bars $1 / 2$ " between glass. Furnished in grade $A$ only. Sticking: Standard.

Beads for glass included.

\section{STORM DOORS}

FS7

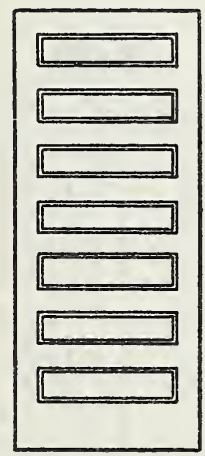

Stiles and top rail.

Intermediate rails

Bottom rail $4 \% 16^{\prime \prime}$ $412^{\prime \prime}$

3-ply laminated flat panels. Can also be furnished with raised panels, if desired. Furnished in 11/" millrun grade only. Sticking: Standard.
FSOT

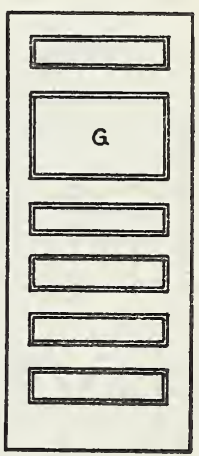

Stiles and top rail

Intermediate rail

Bottom rail

3-ply laminated flat panels. Can also be fur nished with raised panels, if desired. Furnished in $118^{\prime \prime}$ millrun grade only. Sticking: Standard.

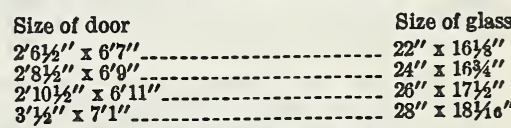

Beads for glass included.

Storm doors made $1 / 2^{\prime \prime}$ over in width and $1^{\prime \prime}$ over in length than corresponding standard size openings. 


\section{CUPBOARD DOORS}

\section{F05}

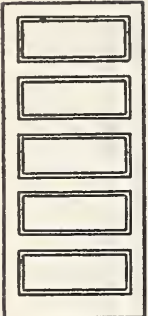

Stiles, top and cross rails. $2 \% / 20$ Bottom rail............. $432^{\prime \prime}$
F020

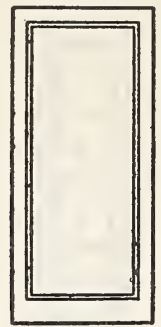

Stiles and top rall ........ 284"

\section{F082}

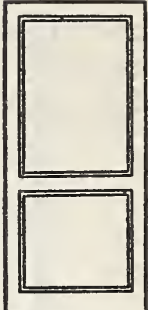

Stiles and top rail.

Cross rail.

$312^{\prime \prime}$

F05 doors are made as below:

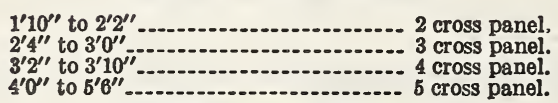

3-ply laminated flat panels.

F05 can be furnished with raised panels.

Cupboard doors made in $B$ and better grade only.

Sticking: Standard

\section{GARAGE DOORS}

\section{F491}

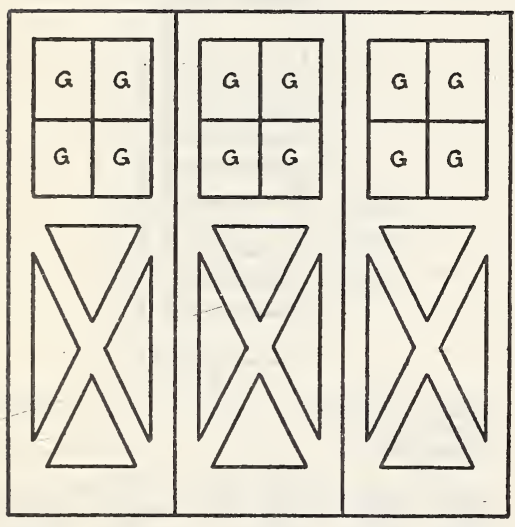

Stiles

Top and lock rails Bottom rail

Vertical bars $5 / 8$ " between glass. Horizontal bars $1^{\prime \prime}$ between glass. Ceiling panels. Cross hraces screwed on. Sticking: Standard. Beads for glass included.
F691

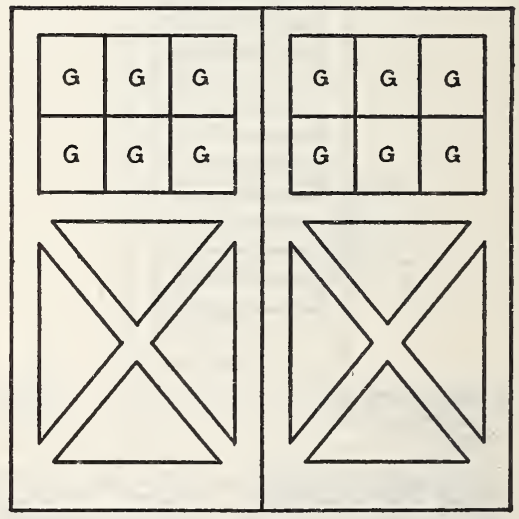

Stiles, top and lock rails Bottom rail

Vertical and horizontal bars $1^{\prime \prime}$ between glass. Ceiling pancls. Cross braces screwed on. Sticking: Standard. Beads for glass included. 
F493

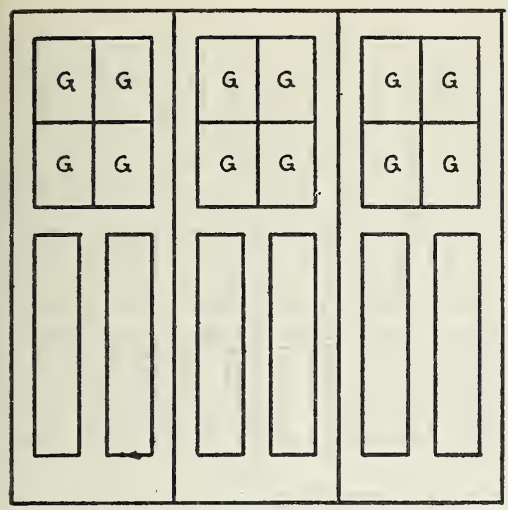

Stiles $4 \% 16^{\prime \prime}$ Top and lock rails.... $538^{\prime \prime}$ Muntin Bottom rail...

Vertical bars, $5 / 8 "$ between glass.

Horizontal bars, 1 " between glass.

3-ply laminated flat panels. Can also bo fur nished with raised panels, if desired. Bticking: Standard.

Beads for glass included.

$F 495$

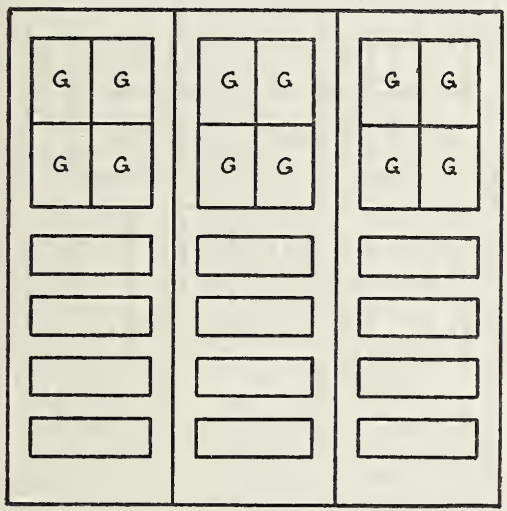

Stiles.

$4 \% 0^{\prime \prime}$

Top and lock rails

Intermediate rail

Vertical bars, 58 " between glass.

Horizontal bars, 1 " between glass.

3-ply laminated flat panels. Can also be fur. nished with raised panels, if desired.

Sticking: Standard.
F693

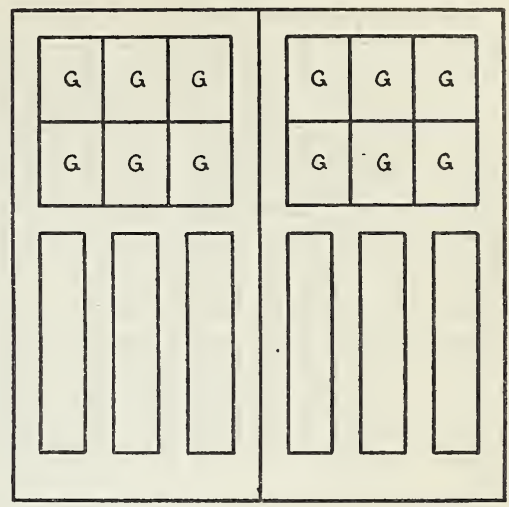

Stiles, top and lock rails

$538^{\prime \prime}$

Muntins and lock rails...... $536^{\prime \prime}$

Bottom rail

Vertical and horizontal bars, 1 " between glass.

3-ply laminated flat panels. Can also be fur. nished with raised panels, if desired.

Sticking: Standard.

Beads for glass included.

F695

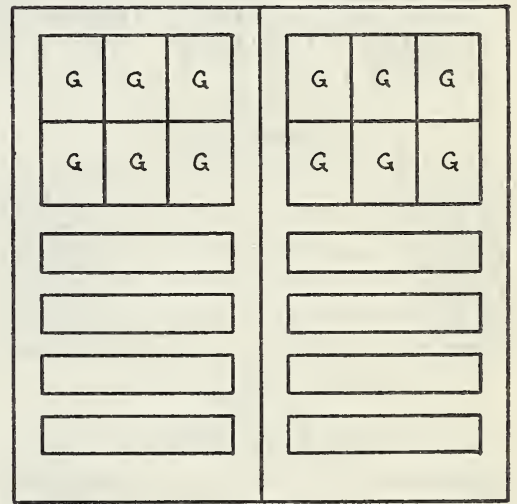

Stiles, top and lock rails._................ 53/" Intermediate rails. Bottom rail. .............. 938

Vertical and horizontal bars, $1 "$ between glass.

3-ply laminated flat panels. Can also be fur. nished with raised panels, if desired.

Sticking: Standard.

Beads for glass included.

Beads for glass included.

For standard glass sizes of garage doors, see page 28. 
F496

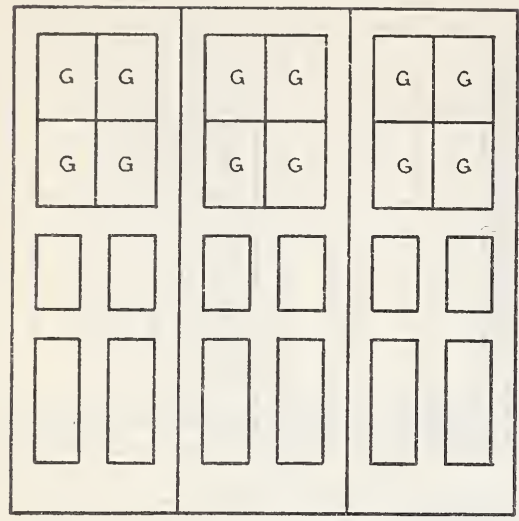

Stiles.

$4 \% 16^{\prime \prime}$

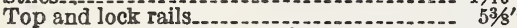
Intermediate rail and muntins.............. $538^{\prime \prime}$ Bottom rail.

Vertical bars $5 / 8^{\prime \prime}$ between glass. Horizontal bars $1^{\prime \prime}$ between glass. 3-ply laminated flat panels. Can also be furnished with raised panels, if desired. Sticking: Standard.

Beads for glass included.

\section{STANDARD GLASS OPENINGS FOR STANDARD GARAGE DOOR DESIGNS SHOWN ABOVE \\ SETS}

4 lights per door

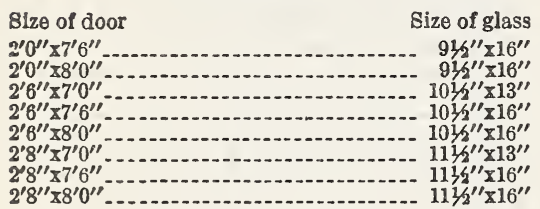

PAIRE

6 lights per door

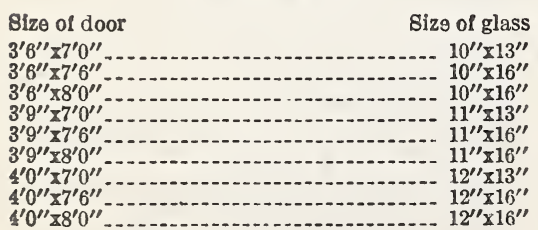

F 696

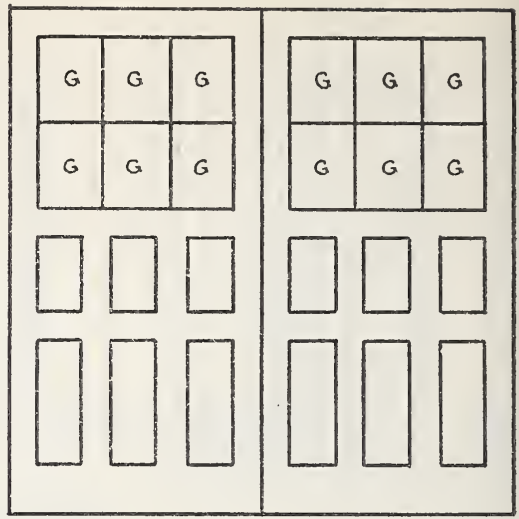

Stiles, top and lock rails..................... 536 Intermediate rail and muntins ............ $538^{\prime \prime}$ Bottom rail .......................... $938^{\prime \prime}$ Height of top panels $95 \% 8^{\prime \prime}$, shoulder to shoulder.

Vertical and horizontal bars $1^{\prime \prime}$ between glass 3-ply laminated flat panels. Can also be furnished with raised panels, if desired. Sticking: Standard.

Beads tor glass included.

F894

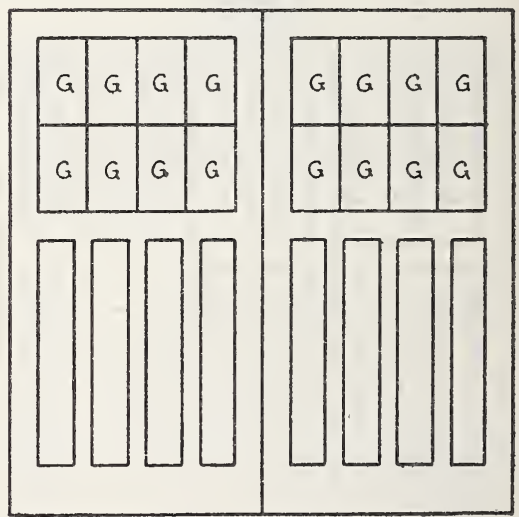

Stiles, top and lock rails _..................... $53 / 8^{n}$ Muntins Bottom rail . . . . . .

Vertical bars $5 / 8^{\prime \prime}$ between glass. Horizontal bars $1^{\prime \prime}$ between glass. 3-ply laminated flat panels. Can also be furnished with raised panels, if desired. Sticking: Standard.

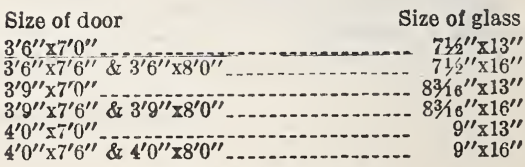

Beads for glass included. 
F093

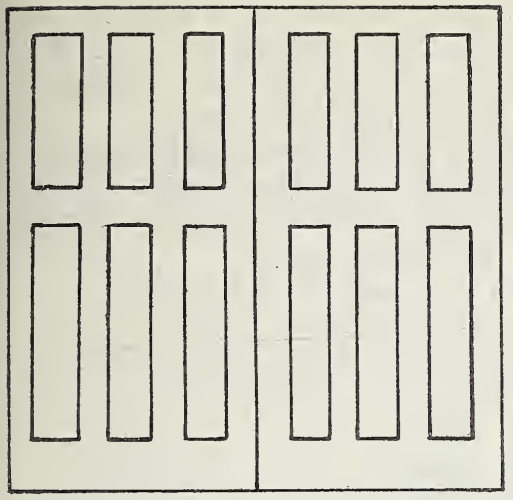

Stiles, top and lock rails._................... $538^{\prime \prime}$ Muntins Bottom rail . . .

3-ply laminated flat panels. Can also be furnished with raised panels, if desired. Sticking: Standard.

\section{F190}

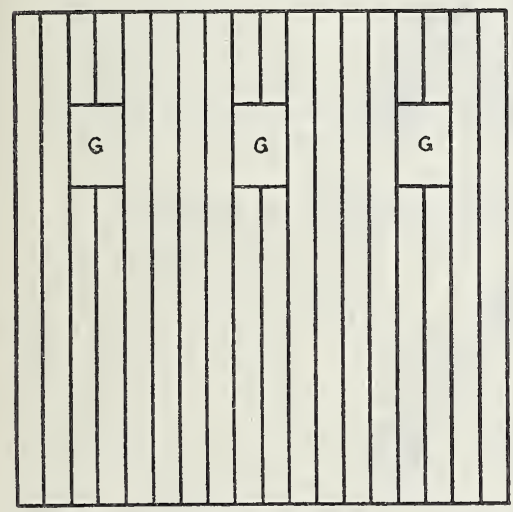

v.G. flush garage door in sets, with standard glass openings, as shown, or without glass openings

(bach side of each door with 6 batts ("V" celling strips) wide, 5 "V" grooves.

Stiles full thickness of door with intervening celling strips glued and nailed to core.

Sets of 3 standard width of each door $2^{\prime} 8^{\prime \prime}$, glass size $1058^{\prime \prime} \leq 16^{\prime \prime}$, berds tacked in.

One light per door, standard, placed $18^{\prime \prime}$ from top of door.

Metal bars or leaded glass recommended for divided light effect, if desired.

Made in 13/4" thickness only.
F099

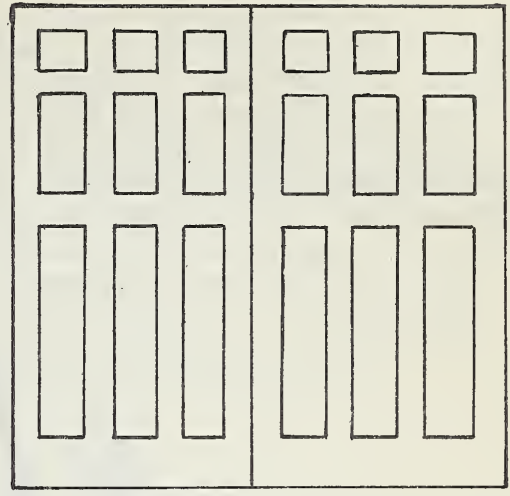

Stiles, top and lock rails $53 / 3^{\prime \prime}$ Intermediate rails and muntin Bottom rail . .............. $93 / 8^{\prime \prime}$

3-ply laminated flat panels. Can also be furnished with raised panels, if desired. Sticking: Standard.

F290

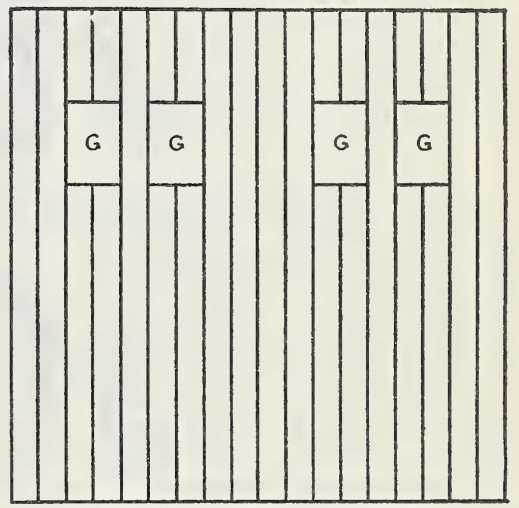

V.G. flush garage door in pairs, with standard glass openings, as shown, or without glass openings (blank).

Each side of each door with 9 batts ("V" ceiling strips) wide, 8 "V" grooves.

Stiles full thickness of door with intervening ceiling strips glued and nailed to core.

standard width of each door in pairs, $4^{\prime} 0^{\prime \prime}$, glass size $1058^{\prime \prime} \times 16^{\prime \prime}$, beads tacked in.

Two lights per door, standard, placed $18^{\prime \prime}$ from top of door.

Metal bars or leaded glass recommended for divided light effect, if desired. Made in 13/" thickness only. 


\section{GRADE MARIKING}

37. The following sets forth the grade marking rules adopted by the Fir Door Institute to preserve the high standards of quality herein recorded and to insure distributors and ultimate consumers receiving the proper grade of fir door for their specific needs:

38. All fir doors guaranteed to conform to the commercial standard grading rules shall be marked or branded with the letters "FDI" followed by the numerals designating the particular manufacturer. (The numerals 00 are used here only for illustration.)

38 (a). All fir doors of $A$ grade shall be stamped or branded

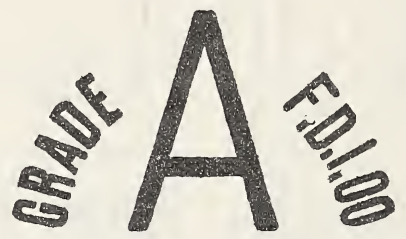

38.(b). All fir doors of $B$ grade shall be stamped or branded

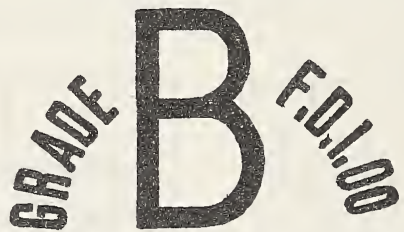

38 (c). All fir doors of $C$ grade shall be stamped or branded

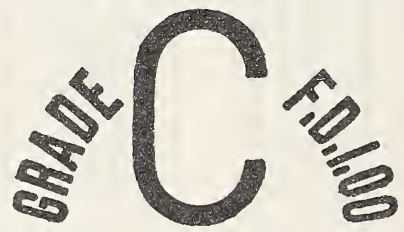

38 (d). All fir doors of "Millrun" grade shall be stamped or branded

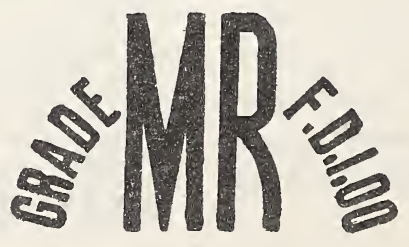

EFFECTIVE DATE

The standard is effective for new production from June 15, 1943. 


\section{STANDING COMMITTEE}

The following individuals comprise the membership of the standing committee, which is to review, prior to circulation for acceptance, revisions proposed to keep the standard abreast of progress. Each organization nominated its own representatives. Comment concerning the standard and suggestions for revision may be addressed to any member of the committee or to the Division of Trade Standards, National Bureau of Standards, which acts as secretary for the committee.

\section{Manufacturers:}

W. P. Woolley (chairman), M and M Wood Working Co., Portland, Oreg.

Henry L. Mertz, Buffelen Lumber and Manufacturing Co., Tacoma, Wash.

N. O. Cruver, Wheeler Osgood Sales Corporation, Tacoma, Wash.

D. C. SAlley, Northwest Door Co., Tacoma, Wash.

Distributors:

C. F. Knecht, W. P. Fuller and Co., Tacoma, Wash.

Fred TibBeTtS, Brockway-Smith-Haigh-Lovell Co., Boston, Mass.

Lionel RAY, Huttig Sash and Door Co., 1000-1300 S. Vandeventer Ave., St. Louis, Mo.

Don A. CAMPBELL, Bonner Campbell Co., Lebanon, Ky., Representing National Retail Lumber Dealers Association.

George W. LaPointe, Jr., O. and N. Lumber Co., 620 Main St., Menominee, Wis.

Users:

H. P. Vermilya, Technical Division, Federal Housing Administration, Washington, D. C.

Theodore Irving Coe, The American Institute of Architects, The Octagon, 1741 New York Ave., Washington, D. C.

Nelson J. Morrison, Room 228, Perkins Bldg., Tacoma, Wash., Representing The American Institute of Architects.

\section{HISTORY OF PROJECT}

On January 25, 1938, the Fir Door Institute requested the cooperation of the Division of Trade Standards in bringing together all interested parties for the development and establishment of standards for stock fir doors. A draft of the preliminary standard was sent on March 11, 1938, to a comprehensive list of those interested in the production, distribution, sale, and use of this commodity. On April 4, 1938, a general conference was held at Tacoma, Wash., for the public discussion of the proposed standard. Some modifications were made and the conference unanimously passed a resolution that the standard, as modified, be circulated for public acceptance as the commercial standard of the industry. This was done on April 28, 1938. Following satisfactory acceptance and in the absence of active opposition, the establishment of the commercial standard, designated as CS73-38, was announced on June 30, 1938, to become effective for new production immediately.

\section{FIRST REVISION}

On January 4, 1943, the Fir Door Institute submitted a proposed revision which included two new door layouts and a slight modification in the requirements for panels and bottom rails for grade $A$ and grade $B$ doors. These changes were approved by the Standing Committee, and the recommended revision was circulated on February 27, 1943 to those directly concerned for written acceptanee.

Following acceptance by a satisfactory majority, the success of the revision was announced on May 15, 1943. 



\section{ACCEPTANCE OF COMMERCIAL STANDARD}

This sheet properly filled in, signed, and returned will provide for the recording of your organization as an acceptor of this commercial standard.

Division of Trade Standards,

Date

National Bureau of Standards;

Washington, D. C.

Gentlemen:

Having considered the statements on the reverse side of this sheet, we accept the Commercial Standard CS 73-43 as our standard of practice in the

Production $^{1} \quad$ Distribution ${ }^{1}$

of old growth Douglas fir standard stock doors.

We will assist in securing its general recognition and use, and will cooperate with the standing committee to effect revisions of the standard when necessary.

Signature of individual officer

\section{(In ink)}

(Kindly typewrite or print the following lines)

Name and title of above officer

Company

(Fill in exactly as it should be listed in pamphlet)

Street address

City and State

1 Please designate which group you represent by drawing lines through the other two. Please fle separate acceptances for all subsidiary companies and affiliates which should be listed separately as acceptors. In the case of related interests, trade papers, colleges, etc., desiring to record their general approval, the words "in principle" should be added after the signature. 


\section{TO THE ACCEPTOR}

The following statements answer the usual questions arising in connection with the acceptance and its significance:

1. Enforcement.-Commercial standards are commodity specifications voluntarily established by mutual consent of the industry. They present a common basis of understanding between the producer, distributor, and consumer and should not be confused with any plan of governmental regulation or control. The United States Department of Commerce has no regulatory power in the enforcement of their provisions; but, since they represent the will of the industry as a whole, their provisions through usage soon become established as trade customs, and are made effective through incorporation into sales contracts, by means of labels, invoices, and the like.

2. The acceptor's responsibility. - The purpose of commercial standards is to establish for specific commodities, nationally recognized grades or consumer criteria, and the benefits therefrom will be measurable in direct proportion to their general recognition and actual use. Instances will occur when it may be necessary to deviate from the standard, and the signing of an acceptance does not preclude such departures; however, such signature indicates an intention to follow the commercial standard where practicable, in the production, distribution, or consumption of the article in question.

3. The Department's responsibility. - The major function performed by the Department of Commerce in the voluntary establishment of commercial standards on a Nation-wide basis is fourfold: First, to act as an unbiased coordinator to bring all branches of the industry together for the mutually satisfactory adjustment of trade standards; second, to supply such assistance and advice as past experience with similar programs may suggest; third, to canvass and record the extent of acceptance and adherence to the standard on the part of producers, distributors, and users; and fourth, after acceptance, to publish and promulgate the standard for the information and guidance of buyers and sellers of the commodity.

4. Announcement and promulgation.-When the standard has been endorsed by companies representing a satisfactory majority of production, the success of the project is announced. If, however, in the opinion of the standing committee of the industry or the Department of Commerce, the support of any standard is inadequate, the right is reserved to withold promulgation and publication. 


\section{ACCEPTORS}

The organizations and individuals listed below have accepted these grading specifications as their standard of practice in the production, distribution, and use of Douglas fir stock doors. Such endorsement does not signify that they may not find it necessary to deviate from the standard, nor that producers so listed guarantee all of their products in this field to conform with the requirements of this standard. Therefore, specific evidence of quality certification should be obtained where required.

\section{ASSOCIATONS}

American Specification Institute, Chicago, Ill.

Arizona Retail Lumber \& Builders Supply Association, Inc., Phoenix, Ariz.

Associated General Contractors of America, Inc., Washington, D. C.

Associated General Contractors of Massachusetts, Inc., Boston, Mass.

Carolina Lumber \& Building Supply Association, Charlotte, N. C. (In Principle.)

Douglas Fir Plywood Association, Tacoma, Wash.

Fir Door Institute, Tacoma, Wash.

Michigan Retail Lumber Dealers, Lansing, Mich.

National Hardwood Lumber Association, Chicago, Ill. (In Principle.)

New York Lumber Trade Association, New York, N. Y.

Southern California Retail Lumber Association, San Diego, Calif.

Southern Hardwood Producers, Inc., Memphis, Tenn. (In Principle.)

West Coast Lumbermen's Association, Seattle, Wash. (In Principle.)

Wisconsin Retail Lumbermen's Association, Milwaukee, Wis.

\section{FIRMS}

Acme Door Co., Hoquiam, W,ash. Addison-Rudesal Co., Atlanta, Ga.

Adkins \& Co., E. S., Salisbury, Md.

Allan Lumber Co., Inc., Greencastle, Ind.

Allen Lumber Co., Elwood, Philadelphia, $\mathrm{Pa}$.

Altfillisch, Charles, Decorah, Iowa.

American Forest Products Corporation, New York, N. Y.

American Houses, Inc., New York, N. Y.

American Sash \& Door Co., Kansas City, Mo,

Andrews Lumber Co., C. E., New Bethlehem, $\mathrm{Pa}$.

Angelina County Lumber Co., Keltys, Tex.

Arizona Sash Door \& Glass Co., Phoenix Ariz. and Tucson, Ariz.

Arkmo Lumber Co., The, Little Rock, Ark.
Ashton Co., C. J., Detroit, Mich.

Bahe Co., Inc., Edward J., Chicago, Ill.

Baltimore, Bureau of Plans \& Surveys of, Baltimore, Md.

Bardwell-Robinson Co., Fargo, N. Dak

Barkhorn Co., Wm. H., Newark, N. J.

Barnes Lumber Co., W. F. \& J. F., Waco, Tex.

Barr \& Collins, Forest Park, Ill.

Beasley \& Sons Co., Nashville, Tenn.

Becker Coal \& Builders Suppiy Co., Wilmington, N. C.

Becker-Danowitz Co., Inc., Brooklyn, N. Y.

Bell Manufacturing Co., Inc., C. C., West Monroe, La.

Bennett-Bailey Lumber Co., Minneapolis, Minn.

Beresford, Robert F., Washington, D. C

Berger, F. E.-R. L. Kelley, Champaign, Ill.

Beuttler, Wm., Sioux City, Iowa.

Billings Sash \& Door Co., Billings, Mont.

Binswanger \& Co., Inc., Richmond, Va.

Birmingham Sash \& Door Co., Birmingham, Ala.

Bishop, Horatio W., La Mesa, Calif.

Blake, Edgar Ovet, Evanston, Ill.

Blithe, Wesley Lesher, Philadelphia, Pa.

Bloedel-Donovan Lumber Mills, Bellingham, Wash.

Boehm, George A., New York, N. Y.

Bohnhoff Lumber Co., Inc., Los Angeles, Calif.

Borland Lumber Co., Oil City, Pa.

Bosman \& Casson, Harrison, N. J.

Bovard, William R., Kansas City, Mo.

Braseth \& Houkom, Fargo, N. Dak.

Brazer, Clarence W., New York, N. Y.

Brew Manufacturing Co., Puyallup, Wash

Bristol Door \& Lumber Co., Bristol, Va.

Brittain \& Cannon Co., Watertown, Mass.

Brockway-Smith-Haigh-Lovell Co., Boston, Mass.

Brown-Graves Co., Akron, Ohio.

Brust \& Brust, Milwaukee, Wis.

Buckley Door Co., F. S., San Francisco, Calif.

Bucky, Fred W., Jr., Jacksonville, Fla. 
Buffalo Plywood Corporation, Buffalo, N. Y.

Buffelen Lumber \& Manufacturing Co., Tacoma, Wash., Fort Worth, Tex., and Detroit, Mich.

Builders Supply Co., Bismarck, N. Dak.

Building Service, Inc., Great Falls, Mont.

Building Supplies Corporation, Norfolk, Va.

Burritt Co., The A. W., Bridgeport, Conn.

Byron Sash \& Door Co., Inc., Louisville, $\mathrm{Ky}$.

C. \& M. Construction Co., Inc., Philadelphia, $\mathrm{Pa}$.

C-W Plywood Co., Chicago, Ill.

California Builders Supply Co., Ltd., Oakland, Calif.

California Door Co., The, Los Angeles, Calif.

Cameron \& Co., Inc., Wm., Waco, Tex.

Cameron Lumber Co., Inc., Newburgh, N. Y.

Camlet, J. Thomas, Passaic, N. J.

Camp Plywood Co., Inc., The E. W., Indianapolis, Ind.

Cannon \& Mullen, Salt Lake City, Utah.

Carroll, John, Ventnor, N. J.

Carroll Lumber Co., Inc., The, Alexandria, La.

Cavalier Corporation, Chattanooga, Tenn.

Cavanagh Lumber Co., Petaluma, Calif.

Cellar Lumber Co., W esterville, Ohio.

Central Glazing Co., Fort Worth, Tex.

Central Jersey Wholesale Supply Co., Trenton, N. J.

Central Wholesale Co., Inc., Shreveport, La.

Cervin \& Stuhr, Rock Island, Ill.

Chapin, Rollin C., Minneapolis, Minn. (In Principle.)

Chapin Lumber Co., The, Aurora, Colo.

Charlottesville Lumber Co., Inc., Charlottesville, Va.

Chase Lumber Co., S. H., San Jose, Calif.

Chicago \& Riverdale Lumber Co., Chicago, Ill.

Chicago, Rock Island \& Pacific Railway Co., Chicago, Ill.

Christmann Veneer \& Lumber Co., St. Louis, Mo.

Cincinnati Sash \& Door Co., The, Cincinnati, Ohio.

Clark Venner Co., Walter, Grand Rapids, Mich.

Cleary Millwork Co., Inc., Ansonia, Conn.

Cleveland Window Glass \& Door Co., Cleveland, Ohio.

Collier-Barnett Co., The, Toledo, Ohio.

Combs Lumber Co., Inc., Lexington, $\mathrm{Ky}$.

Connecticut, State of, Supervisor of Purchases, Hartford, Conn.
Conrad \& Cummings, Binghamton, N. Y.

Conwell \& Co., E. L., Philadelphia, Pa. (In Principle.)

Coolbaugh \& Son Co., C. C., Gloucester City, N. J.

Coolidge, Shepley, Bulfinch \& Abbott, Boston, Mass.

Cordele Sash, Door \& Lumber Co., Cordele, Ga.

Crawford Manufacturing Co., El Paso, Tex.

Cross Austin \& Ireland Lumber Co., Brooklyn, N. Y.

Crowell \& Lancaster, Bangor, Maine.

Curtis Co., Ros, Detroit, Mich.

Dakota Sash \& Door Co., Aberdeen, S. Dak.

D'Arcy Co., Dover, N. H.

Davidson Sash \& Door Co., Austin, Tex.

Davidson Sash \& Door Co., Inc., Lake Charles, La.

Davis Hardwood Co., San Francisco, Calif.

Davis Millwork Co., Forty Fort, Pa.

De Jarnette, Charles Wagner, Des Moines, Iowa.

Dealers Wholesale Supply, Inc., Detroit, Mich.

Delehanty, Andrew L., Albany, N. Y.

Derr Co., Wm. H., Philadelphia, Pa.

Dibble Lumber Co., The S. B., North Adams, Mass.

Doddington Corporation, The, Columbus, Ohio.

Doerr, J. G., Boise, Idaho.

Donlin-Johnson Co., St. Cloud, Minn.

Dower Lumber Co., John, Tacoma, Wash.

Dunlap \& Co., Inc., Columbus, Ind.

Dyke Bros., Fort Smith, Ark.

Dykes Lumber Co., New York, N. Y.

Elmer Co., J. O., San Francisco, Calif.

Elmer \& Moody Co., Seattle, Wash.

Emery Industries, Inc., Cincinnati, Ohio.

Emmons-Hawkins Hardware Co., Huntington, W. Va.

Empire Millwork Co., Corona, N. Y.

Engler Millwork Corporation, Jersey City, N. J.

Erdelen, Arthur F., St. Louis, Mo. (In Principle.)

Estes Lumber Co., Birmingham, Ala.

Evans-Lee Co., Eau Claire, Wis.

Evans-MacArthur Co., New York, N. Y.

Exchange Lumber \& Manufacturing Co., Spokane, Wash.

Fink \& Schindler Co., The, San Francisco, Calif.

Fischer Lime \& Cement Co., Memphis, Tenn.

Fish \& Hunter Co., The, Rapid City, S. Dak.

Fitz-Gibbon, T. David, Norfolk, Va.

Flannagan, Eric G., Henderson, N. C. 
Flint Sash \& Door Co., Inc., Flint, Mich.

Florida, University of, Department of Architecture, Board of Control, Gainesville, Fla.

Folse, Edgar P., New Iberia, La.

Forrest Lumber Co., Lamesa, Tex.

Fort Wayne Builders Supply Co., Fort Wayne, Ind.

Fort Wayne Lumber Co., Fort Wayne, Ind.

Foster \& Co., James P., Baltimore, Md. Foster Lumber Co., R. S., Indianapolis, Ind.

Fuller \& Co., W. P., Boise, Idaho, and other cities.

Galion Lumber Co., The, Galion, Ohio. Gall, Harry L. C., New York, N. Y.

General Millwork Corporation, Utica, N. Y.

Georgeson, F. T., Eureka, Calif.

Gibson Door Co., The, Utica, N. Y.

Gilbert Co., Hawley, Portland, Oreg.

Ginsberg \& Sons, Inc., D., Corona, N. Y.

Glasson Mill \& Lumber Co., San Diego, Calif.

Gourley \& Co., John, Highland Park, Ill.

Great Lakes Sash \& Door Co., The, Cleveland, Ohio.

Griffin Manufacturing Co., A. T. Goldsboro, N. C.

Hahn, Stanley W., Silver Spring, Md.

Haley Bros., Santa Monica, Calif.

Hall-Gregg, Inc., Somerville, Mass.

Hannaford \& Sons, Samuel, Cincinnati. Ohio.

Haralson \& Mott, Fo:t Smith, Ark.

Harbor Plywood Corporation, Hoquiam, Wash., and other cities.

Harbor Sales Co., Inc., The, Baltimore, Md., and Washington, D. C.

Harrison Co., The W. H., Grand Island, Nebr.

Hartung Co., F. L., Seattle, Wash.

Hasness, Carlisle D., Harrisburg, Pa.

Hastings \& Co., Inc., A. W., West Somerville, Mass.

Hawkins Lumber \& Warehouse Co., Boston, Mass.

Haxby \& Bissell, Minneapolis, Minn.

Helfensteller, Hirsch \& Watson, St. Louis, Mo.

Heidritter Lumber Corporation, Elizabeth, N. J.

Henderlong Lumber Co., Inc., Crown Point, Ind.

Higgins Lumber Co., J. E., San Francisco, Calif.

Hilty-Forster Lumber Co., Milwaukee, Wis.

Hines Lumber Co., Edward, Chicago, Ill.

Hoffman Co., Earl, Los Angeles, Calif. Hogan Lumber Co., Oakland, Calif.

Holsman \& Holsman, Chicago, Ill.

Hope, Frank L., Jr., San Diego, Calif.
Hotchkiss Brothers Co., The, Torrington, Conn.

Houston Sash \& Door Co., Houston, Tex.

Hubbell Hardwood Door Co., New Rochelle, N. Y.

Huber-Lanctot Housewrecking Corporation, Buffalo, N. Y.

Hunter Lumber Co., Chillicothe, Ill.

Hurd-Most Sash \& Door Co., Dubuque, Iowa.

Huttig Sash \& Door Co., Dallas, Tex., and other cities.

Hyde-Murphy Co., Ridgway, Pa.

Illinois Valley Manufacturing Co., Peru, Ill.

Independent Lumber Co., The, Grand Junction, Colo.

Indiana Lumber \& Manufacturing Co., South Bend, Ind.

Interstate Lumber Co., Missoula, Mont.

Interstate Sash \& Door Co., The, Canton, Ohio, and Cleveland, Ohio.

Iron City Sash \& Door Co., Pittsburgh, $\mathrm{Pa}$.

Iron Mountain, City Lumber Yard of, Iron Mountain, Mich.

Iroquois Door Co., Buffalo, N. Y.

Ivey, Inc., Edwin J., Seattle, Wash.

Jacksonville Sash \& Door Co., Jacksonville, Fla.

Jefferson Wood Products, Co., Jefferson, Wis.

Jennings' Sons, S. P., New Castle, Ind.

Jersey Millwork Corporation, Jersey City, N. J.

Kahn Associated Architects \& Engineers, Inc., Albert, Detroit, Mich.

Karcher \& Smith, Philadelphia, Pa.

Keely Plywood Co., Hal, Pittsburgh, Pa.

Keely \& Sons, S. S., Philadelphia, Pa.

Keen-Coal \& Supply Co., Batavia, Ohio.

Keich \& O'Brien, Warren, Ohio.

Kellogg \& Sons Co., Charles C., Utica, N. Y.

Kendrick \& Brown Co., Inc., Glens Falls, N. Y.

Kilham, Hopkins \& Greeley, Boston, Mass.

Koehl \& Son, Inc., John W., Los Angeles, Calif.

Kohn, Robert D., \& Charles Butler, New York, N. Y.

Koll Planing Mill, Ltd., A. J., Los Angeles, Calif.

Kullberg Manufacturing Co., Minneapolis, Minn.

Kyle, Herbert S., Charleston, W. Va., (In Principle.)

Lake Superior Lumber Co., McPherson, Kans.

Larrick, Thomas, Athens, Ohio.

Latenser \& Sons, John, Omaha, Nebr.

Law, Law \& Potter, Madison, Wis.

Leuckel \& Co., Inc., A. K., Trenton, N. J. 
Levy, Will, St. Louis, Mo.

Lewis Lumber Co., Spring Lake, N. J.

Liberty Lumber \& Manufacturing Co., Inc., Erwin, Tenn.

Loeb, Laurence M., White Plains, N. Y.

Long Fir Gutter Co., Cadiz, Ohio.

Los Angeles, City of, Los Angeles, Calif.

Lowell, Inc., J. B., Worcester, Mass.

Lumber \& Millwork Co. of Philadelphia, The, Philadelphia, $\mathrm{Pa}$.

Lumbermen's Credit \& Warehouse Co., Kalamazoo, Mich.

Lyman-Hawkins Lumber Co., The, Akron, Ohio.

Lynchburg Lumber Manufacturing Co., Inc., Lynchburg, Va.

Lyon-Gray Lumber Co., Dallas, Tex.

M. \& M. Wood Working Co., Portland, Oreg.

Mahoney Sash \& Door Co., The, Canton, Ohio.

Markland Contracting Co., M. B., Atlantic City, N. J.

Marquard Sash \& Door Mfg. Co., The, Cleveland, Ohio.

Martin, Edgar, Chicago, Ill.

Martin Lumber Co., Springfield, Mass.

Marvin Millwork, Inc., Ellenville, N. Y.

Mason City Millwork Co., Mason City, Iowa.

Mason \& Co., George D., Detroit, Mich.

Mason \& Sons, Inc., A., Peru, N. Y.

Massena \& duPont, Inc., Wilmington, Del.

Mauran, Russell, Crowell \& Mullgardt, St. Louis, Mo.

McGoldrick Lumber Co., Spokane, Wash.

McCrady-Rodgers Co., Braddock, Pa.

McGowin-Lyons Hardware \& Supply Co., Mobile, Ala.

McPhillips Manufacturing Co., Mobile, Ala.

Memphis Sash \& Door Co., Memphis, Tenn.

Merrick Lumber Co., Holyoke, Mass.

Michigan Wholesalers, Inc., Jackson, Mich., and Fort Wayne, Ind.

Miller Bros., Inc., Lebanon, Pa.

Miller \& Yeager, Terre Haute, Inc.

Mock \& Morrison, Tacoma, Wash.

Monarch Door \& Manufacturing Co., Tacoma, Wash.

Mooser, William, San Francisco, Calif.

Morgan, David H., Philadelphia, Pa.

Morgan Millwork Co., Baltimore, Md.

Morgan Sash \& Door Co., Oklahoma City, Okla.

Morris Plains Lumber \& Coal Co., The, Morris Plains, N. J.

Morrison-Merrill \& Co., Salt Lake City, Utah.

Muhlenberg Bros., Reading, Pa.

Mundie, Jensen, Bourke, \& Havens, Cnicago, Ill.

Nash, Robinson \& Co., Waco, Tex.
Nashville Sash \& Door Co., Nashville, Tenn.

National Plywood Co., Inc., New York, N. Y.

National Plywoods Inc., Chicago, Ill. Neal-Blun Co., Savannah, Ga.

Nelson, Albert L., St. Louis, Mo.

Neumann \& Sons, William, Jersey City, N. J.

Newton Co., F. H., North Cambridge, Mass.

Newton Lumber Co., The, Pueblo, Colo. Nicolai Door Sales Co., San Francisco, Calif.

Northern Lumber Co., Billings, Mront.

Northwest Door Co., Tacoma, Wash.

Nurenburg, W. S., Fort Worth, Tex.

O. \& N. Lumber Co., Menomonie, Wis.

Oettinger Lumber Co., Greensboro, N. C.

Officer, Gwynn, Berkeley, Calif.

Ohio City Sash \& Door Co., Dayton, Ohio.

O'Neill Manufacturing Co., Inc., Rome, Ga.

Orth, H. W., St. Paul, Minn. (In Principle.)

Pacific Mutual Door Co., Chicago, Ill., and St. Paul, Minn.

Palmer Lumber \& Manufacturing Co., Chehalis, Wash.

Parker Building Specialties, Inc., San Francisco, Calif.

Parshelsky Bros., Inc., Brooklyn, N. Y. Patten-Blinn Lumber Co., Los Angeles, Calif.

Pease Woodwork Co., Inc., Cincinnati, Ohio.

Pennsylvania State College, The, Department of Forestry, State College, $\mathrm{Pa}$. (In Principle.)

Pepper, Geo. W., Jr., Philadelphia, Pa.

Pierre \& Wright, Indianapolis, Ind.

Pinellas Lumber Co., St. Petersburg, Fla.

Pittsburgh Board of Public Edication, Pittsburgh, Pa.

Platt \& Bros., F. P., New York, N. Y.

Portsmouth Lumber Corporation, Portsmouth. Va.

Prassel Sash \& Door Co., San Antonio, Tex.

Prescott Lumber Co., Prescott, Ariz.

Progress Lumber Co., Redwood City, Calif.

Purves \& Cope, Philadelphia, Pa.

Queen City Sash \& Door Co., The, Cincinnati, Ohio.

Quigley Co., J. R., Gloucester City, N. J.

Radford \& Sanders, Inc., Baltimore, Md.

Ramsey \& Sons, Inc., A. H., Miami, Fla.

Ream Co., George E., Los Angeles, Calif. 
Red River Lumber Co., The, Los Angeles, Calif.

Reis Lumber Co., J. B., Belleville, Ill. Remington Yards, Hibbing, Minn.

Resnikoff, Abraham, New York, N. Y. Robbins Door \& Sash Co., Scranton, Pa., and other cities.

Robert \& Co., Inc., Atlanta, Ga.

Roberts Corporation, U. N., Davenport, Iowa.

Robinson Lumber Co., Fred J., Detroit, Mich.

Robinson Manufacturing Co., Everett, Wash.

Rockwell Bros. \& Co., Houston, Tex.

Rockwell Lumber Co., Houston, Tex.

Roddis Lumber \& Veneer Co., Milwaukee, Wis.

Roemer Bros. Lumber Co., Bowling Green, $\mathrm{Ky}$.

Rogers Lumber Co., The I. H., Oklahoma City, Okla.

Rohrer Lumber Co., D. J., Clintonville, $\mathrm{W}$ is.

Rose \& Sons, W. J., Johnstown, Pa.

Rosenberg \& Forbes Co., Inc., Benton Harbor, Mich.

Rounds \& Porter Co., Wichita, Kans.

Rudinger, Inc., C. R., South Kearny, N. J.

Ruggles Lumber Co., Carlos, Springfield, Mass.

Rust Sash \& Door Co., Kansas City, Mo.

Saint Paul \& Tacoma Lumber Co., Tacoma, Wash.

Santa Fe Builders Supply Co., Santa Fe, N. Mex.

Schell-Sasse Manufacturing Co., Jacksonville, Fla.

Schroeder Hardwood Lumber Co., Alexander, Houston, Tex.

Schulzke, William H., Moline, Ill.

Scott Sash \& Door Co., Inc., Little Rock, Ark.

Searle \& Chapin Lumber Co., Lincoln, Nebr.

Sears, Roebuck \& Co., Chicago, Ill.

Segelke \& Kohlhaus Co., La Crosse, Wis.

Shannon Sash \& Door Co., Kansas City, Kans.

Shaver, Chas. W., Salina, Kans.

Shenk Co., Henry, Erie, Pa.

Sherman's Sons Co., R. A., Westerly, R. I.

Sibley Lumber Co., F. M., Detroit, Mich.

Sidells, Arthur F., Warren, Ohio.

Simons, Inc., Minneapolis, Minn.

Simpson Logging Co., Plywood \& Door Division, Shelton, Wash.

Sitterding Carneal Davis Co., Inc., Richmond, Va.

Sloan Lumber Co., Fort Worth, Tex.

Smedley Bros. Co., Philadelphia, Pa.

Smith \& Rumery, Inc., Portland, Maine.
Snedaker \& Co., Inc., Frank C., Philadelphia, Pa.

Snell Sash \& Door Co., St. Paul, Minn.

Snellstrom Lumber Co., Eugene, Oreg.

Snow Lumber Co., High Point, N. C.

Sothman Co., The, Grand Island, Nebr.

Southern Counties Gas Co. of California, Los Angeles, Calif.

Southern Door \& Glass Co., Nashville, Tenn.

Southern Sash \& Door Co., Greenville, S. C.

Southwestern Sash \& Door Co., Inc., Albuquerque, N. Mex.

Southwestern Sash \& Door Co., Inc., El Paso, Tex.

Southwestern Sash \& Door Co., Joplin, Mo.

Spahn \& Rose Lumber Co., Dubuque, Iowa.

Specification Record, Chicago, Ill.

Spokane Sash \& Door Co., Spokane, Wash.

Standard Lumber \& Supply Co., Fort Wayne, Ind.

Standard Novelty Works, Inc., Miami, Fla.

Stark \& Co., Kansas City, Mo.

Staub \& Rather, Houston, Tex.

Stillwater Manufacturing Co., The, Stillwater, Minn.

Stoetzel, Ralph E., Chicago, Ill.

Strable Hardwood Co., Oakland, Calif.

Stritzel, John J., Arlington, Va.

Swan Lakes Moulding Co., Klamath Falls, Oreg.

Sweetwater Sash \& Door Co., Sweetwater, Tex.

Tacoma Millwork Supply Co., Tacoma, Wash.

Tacoma Public Library, Tacoma, Wash.

Taylor, Edward Cray \& Ellis Wing, Los Angeles, Calif.

Taylor, Ellery K., Haddonfield, N. J.

Teachout Sash, Door \& Glass Co., The, Dearborn, Mich.

Tennessee Glass Co., Nashville, Tenn.

Texas Sash \& Door Co., Fort Worth, Tex.

Thorne, Henry Calder, Ithaca, N. Y.

Throop-Martin Co., The, Columbus, Ohio.

Toledo Door \& Sash Co., Toledo, Ohio.

Toombs-Fay Co., Springfield, Mo.

Townsend Sash Door \& Lumber Co., Lake Wales, Fla.

Trexler Lumber Co., Allentown, $\mathrm{Pa}$

Tulane Hardwood Lumber Co., Inc., New Orleans, La.

Tulsa Rig Reel \& Manufacturing Co., Tulsa, Okla.

Tuna Manufacturing Co., Bradford, Pa.

Underwood Coal \& Supply Co., Mobile, Ala.

Union Planing Mill, Stockton, Calif.

United Sash \& Door Co., Wichita, Kans. 
Vaưghan \& Sons, Geo. C., Houston, Tex.

Velde Lumber Co., Pekin, Ill.

Vetter Manufacturing Co., Stevens Point, Wis.

Virginia Polytechnic Institute, Blacksburg, Va.

Wagner Manufacturing Co., Cedar Falls, Iowa.

Wahlfeld Manufacturing Co., Peoria, Ill.

Wallis \& Carley Co., Sharon, Pa.

Walsh, Louis A., Waterbury, Conn.

Wanke Panel Co., Portland, Oreg.

Ware \& McClenahan, Salt Lake City, Utah.

Warren Brothers Co., Nashville, Tenn.

Washington Door Co., Tacoma, Wash.

Washington Woodworking Co., Inc., The, Washington, D. C.

Watertown Sash \& Door Co., Watertown, S. Dak.

Weaver, Rudolph, Gainesville, Fla.

Weinel Lumber Co., Aug. F., Columbia, Ill.

Weisberg-Baer Co., The, Astoria, Ill.

Welch, Carroll E., Huntington, N. Y.

West, Albert E., Boston, Mass.

Western Door \& Plywood Corporation, Portland, Oreg.

Western Door \& Sash Co., Oakland, Calif.

Western Hardwood Lumber Co., Los Angeles, Calif.

Western Reserve Lumber Co., The, Warren, Ohio.

Weyerhaeuser Sales Co., Tacoma, Wash.

Wheeler Osgood Sales Corporation, Tacoma, Wash.

Wheelock Inc., E. U., Los Angeles, Calif.

Whissel Lumber Co., Inc., L. N., Buffalo, N. Y.

Whitmer-Jackson Co., The, Cleveland, Ohio, and Buffalo, N. Y.

Whittier Lumber \& Millwork Co., Newark, N. J.
Wholesale Building Supply, Inc., Oakland, Calif.

Wiles-Chipman Lumber Co., St. Louis, Mo.

Wilkinson Co., Inc., The, Indianapolis, Ind.

Williams \& Hunting Co., Cedar Rapids, Iowa.

Willingham \& Co., Chattanooga, Tenn. Willson, Fred F., Bozeman, Mont.

Wilmington Sash \& Door Co., Wilmington, Del.

Wilson, Adrian, Los Angeles, Calif.

Wilson \& Sons, Inc., W. A., Wheeling, W. Va.

Wischmeyer, William F., St. Louis, Mo.

W ood Lumber Co, E. K., Los Angeles, Calif.

Woodruff Lumber Co., Duluth, Minn.

Wright \& Wright, Detroit, Mich. (In Principle.)

Young \& Richardson, Seattle, Wash.

Zenith Mill \& Lumber Co., Oakland, Calif.

\section{U. S. GOVERNMENT}

Agriculture, Department of, $\mathrm{W}$ ashington, D. C.

Federal Housing Administration, Washington, D. C.

Federal Public Housing Authority, W ashington, D. C.

Federal Works Agency, Public Buildings Administration, Washington, D. C. (In Principle.)

Interior, Department of, Office of Indian Affairs, Chicago, Ill., and Salt Lake City, Utah.

Justice, Department of, Bureau of Prisons, Washington, D. C.

Naval Air Station, Lakehurst, N. J.

Navy Yard, Public Works Department, Philadelphia, Pa., and Portsmouth, N. H.

Treasury Department, Washington, D. C. War Department, Washington, D. C., and Buffalo, N. Y.

\section{COMMERCIAL STANDARDS}

CS No.

Item

0-40. Commercial standards and their value to business (third edition)

1-42. Clinical thermometers (third edition).

2-30. Mopsticks.

3-40. Stoddard solvent (third edition).

4-29. Staple porcelain (all-clay) plumbing fixtures.

5-40. Pipe nipples; brass, copper, steel, and wrought iron.

6-31. Wrought-iron pipe nipples (second edition). Superseded by CS 5-40.

7-29. Standard weight malleable iron or steel screwed unions.

8-41. Gage blanks (third edition)

9-33. Builders' template hardware (second edition)

10-29. Brass pipe nipples. Superseded by CS5-40.

11-41. Moisture regains of cotton yarns_second edition)

12-40. Fuel oils (fifth edition)

13-42. Dress patterns (third edition).
CS No.

14-43. Boys' button-on waists, shirts, junior and sport shirts (made from woven fabrics) (third edition)

(E) 15-43. Men's pajamas (made from woven fabrics) (second edition).

16-29. Wall paper.

17-42. Diamond core drill fittings (third edition)

18-29. Hickory golf shafts.

19-32. Foundry patterns of wood (second edition).

20-42. Staple vitreous china plumbing fixtures (third edition).

21-39. Interchangeable ground-glass joints stopcocks, and stoppers (fourth edition).

22-40. Builders' hardware (nontemplate) (second edition).

23-30. Feldspar.

24-43. Screw threads and tap-drill sizes.

25-30. Special screw threads. Superseded by CS2443.

26-30. Aromatic red cedar closet lining. 
CS No.

Item

27-36. Mirrors (second edition).

28-32. Cotton fabric tents, tarpaulins, and covers.

29-31. Staple seats for water closet bowls.

30-31. Colors for sanitary ware.

31-38. Wood shingles (fourth edition).

32-31. Cotton cloth for rubber and pyroxylin coating.

33-43. Knit underwear (exclusive of rayon) (second edition).

34-31. Bag, case, and strap leather.

35-42. Plywood (hardwood and eastern red cedar) (second edition)

36-33. Fourdrinier wire cloth (second edition).

37-31. Steel bone plates and screws.

38-32. Hospital rubber sheeting.

39-37. Wool and part wool blankets (second edition) (withdrawn as commercial standard, July 14, 1941).

40-32. Surgeons' rubher gloves.

41-32. Surgeons' latex gloves.

42-43. Structural fiber insulating board (third edition).

43-32. Grading of sulphonated oils.

44-32. Apple wraps.

45-42. Douglas fir plywood (fifth edition).

46-40. Hosiery lengths and sizes (third edition).

47-34. Marking of gold-filled and rolled-gold-plate articles other than watchcases.

48-40. Domestic burners for Pennsylvania anthracite (underfeed type) (second edition).

49-34. Chip board, laminated chip board, and miscellaneous boards for bookbinding purposes.

50-34. Binders board for bookbinding and other pur-

poses.
51-35. Marking articles made of silver in combination with gold.

52-35. Mohair pile fabrics (100-percent mohair plain velvet, 100-percent mohair plain frieze, and 50 -percent mohair plain frieze).

53-35. Colors and finishes for cast stone.

54-35. Mattresses for hospitals.

55-35. Mattresses for institutions.

56-41. Oak flooring (second edition).

57-40. Book cloths, buckrams, and impregnated fabrics for bookbinding purposes except library bindings (second edition)

58-36. Woven elastic fabrics for use in overalls (overall elastic webbing).

59-41. Woven textile fabrics-testing and reporting (third edition).

60-36. Hardwood dimension lumber.

61-37. Wood-slat venetian blinds.

$62-38$. Colors for kitchen accessories.

63-38. Colors for bathroom accessories.

64-37. Walnut veneers.

65-43. Methods of analysis and of reporting fiber composition of textile products (second edition).

66-38. Marking of articles made wholly or in part of platinum.

67-38. Markiny articles made of karat gold.

68-38. Liquid hypochlorite disinfectant, deodorant, and germicide.

69-38. Pine oil disinfectant.

70-41. Phenolic disinfectant (cmulsifying type) (second edition) (published with CS71-41).
CS No.

Item

71-41. Phenolic disinfectant (soluble type) (second edition) published with CS70-41)

72-38. Household insecticide (liquid spray type).

$73-43$. Old growth Douglas fir standard stock doors (second edition).

74-39. Solid hardwood wall paneling.

75-42. Automatic mechanical draft oil burners designed for domestic installations (second edition).

76-39. Hardwood interior trim and molding.

77-40. Sanitary cast-iron enameled ware.

78-40. Ground-and-polished lenses for sun glasses (second edition) (published with CS79-40).

79-40. Blown, drawn, and dropped lenses for sun glasses (second edition) (published with CS78-40).

80-41. Electric direction signal systems other than semaphore type for commercial and other vehicles subject to special motor vehicle laws (after market).

81-41. Adverse-weather lamps for vehicles (after market).

82-41. Inner-controlled spotlamps for vehicles (after market).

83-41. Clearance, marker, and identification lamps for vchicles (after market).

84-41. Electric tail lamps for vehicles (after market).

85-41. Electric license-plate lamps for vehicles (after market).

86-41. Electric stop lamps for vehicles (after market).

87-41. Red electric warning lanterns.

$88-41$. Liquid-burning flares.

89-40. Hardwood stair treads and risers.

90- . (Reserved for power shovels and cranes.)

91-41. Factory-fitted Douglas fir entrance doors.

92-41. Cedar, cypress, and redwood tank stock lumber.

93-41. Portable electric drills (exclusive of high frequency)

94-41. Calking lead.

95-41. Lcad pipe.

96-41. Lead traps and bends.

97-42. Elcetric supplementary driving and passing lainps for vehicles (after market).

98-42. Artists' oil paints.

99-42. Gas floor furnaces-gravity circulating type.

100-42. Multiple-coated, porcelain-enameled stecl utensils.

101-43. Flue-connected oil-burning space heaters equipped with vaporizing pot type burners.

102- (Reserved for Diesel and fuel-oil engines.)

103-42. Cotton and rayon velour (jacquard and plain).

(E) 104-43. Warm air furnaces equipped with vaporizing pot-type oil burners.

105-43. Mineral wool; loose, granulated, or felted form, in low-temperature installations.

(E) 106-43. Boys' pajamas (made from woven fabrics).

(E) 107-43. Commercial electric-refrigeration condensing units.

108-43. Treading automobile and truck tires.

Notick.-Those interested in commercial standards with a view toward accepting them as a basis of every-day practice may secure copies of the above standards, while the supply lasts, by addressing the Division of Trade Standard. National Bureau of Standards, Washington, D. C. 
